\title{
Biological and toxicological evaluation of Rhus trilobata Nutt. (Anacardiaceae) used traditionally in mexico against cancer
}

Luis Varela-Rodríguez ${ }^{1,2}$ (D), Blanca Sánchez-Ramírez $2^{*}$ (D), Ivette Stephanie Rodríguez-Reyna² (D),

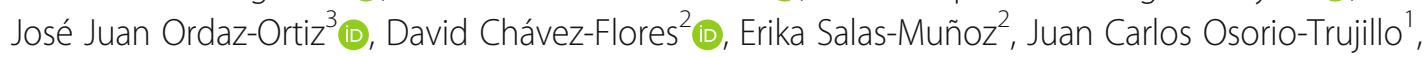
Ernesto Ramos-Martínez ${ }^{4}$ and Patricia Talamás-Rohana ${ }^{1 *}$ (i)

\begin{abstract}
Background: Rhus trilobata Nutt. (Anacardiaceae) (RHTR) is a plant of Mexico that is traditionally used as an alternative treatment for several types of cancer. However, the phytochemical composition and potential toxicity of this plant have not been evaluated to support its therapeutic use. Therefore, this study aimed to evaluate the biological activity of RHTR against colorectal adenocarcinoma cells, determine its possible acute toxicity, and analyze its phytochemical composition.

Methods: The traditional preparation was performed by decoction of stems in distilled water (aqueous extract, AE), and flavonoids were concentrated with $\mathrm{C}_{18}$-cartridges and ethyl acetate (flavonoid fraction, FF). The biological activity was evaluated by MTT viability curves and the TUNEL assay in colorectal adenocarcinoma (CACO-2), ovarian epithelium (CHO-K1) and lung/bronchus epithelium (BEAS-2B) cells. The toxicological effect was determined in female BALB/c mice after $24 \mathrm{~h}$ and 14 days of intraperitoneal administration of $200 \mathrm{mg} / \mathrm{kg} \mathrm{AE}$ and FF, respectively. Later, the animals were sacrificed for histopathological observation of organs and sera obtained by retro-orbital bleeding for biochemical marker analysis. Finally, the phytochemical characterization of AE and FF was conducted by UPLC-MSE.
\end{abstract}

Results: In the MTT assays, AE and FF at 5 and $18 \mu \mathrm{g} / \mathrm{mL}$ decreased the viability of CACO-2 cells compared with cells treated with vehicle or normal cells ( $p \leq 0.05$, ANOVA), with changes in cell morphology and the induction of apoptosis. Anatomical and histological analysis of organs did not reveal important pathological lesions at the time of assessment. Additionally, biochemical markers remained normal and showed no differences from those of the control group after $24 \mathrm{~h}$ and 14 days of treatment ( $p \leq 0.05$, ANOVA). Finally, UPLC-MS ${ }^{\mathrm{E}}$ analysis revealed 173 compounds in AE-RHTR, primarily flavonoids, fatty acids and phenolic acids. The most abundant compounds in AE and FF were quercetin and myricetin derivates (glycosides), methyl gallate, epigallocatechin3-cinnamate, $\beta$-PGG, fisetin and margaric acid, which might be related to the anticancer properties of RHTR. Conclusion: RHTR exhibits biological activity against cancer cells and does not present adverse toxicological effects during its in vivo administration, supporting its traditional use.

Keywords: Acute toxicity, Biological activity, $\beta-P G G$, Colorectal adenocarcinoma, Phytochemical composition, Rhus trilobata

\footnotetext{
*Correspondence: bsanche@uach.mx; ptr@cinvestav.mx

${ }^{2}$ Facultad de Ciencias Químicas, Universidad Autónoma de Chihuahua, Circuito No. 1, Nuevo Campus Universitario, C.P. 31125 Chihuahua, Chih., Mexico

${ }^{1}$ Departamento de Infectómica y Patogénesis Molecular, CINVESTAV-IPN, Ave. Instituto Politécnico Nacional No. 2508, Col. San Pedro Zacatenco, C.P. 07360 Ciudad de México, Mexico

Full list of author information is available at the end of the article
}

(c) The Author(s). 2019 Open Access This article is distributed under the terms of the Creative Commons Attribution 4.0 International License (http://creativecommons.org/licenses/by/4.0/), which permits unrestricted use, distribution, and reproduction in any medium, provided you give appropriate credit to the original author(s) and the source, provide a link to the Creative Commons license, and indicate if changes were made. The Creative Commons Public Domain Dedication waiver (http://creativecommons.org/publicdomain/zero/1.0/) applies to the data made available in this article, unless otherwise stated. 


\section{Background}

Plants have traditionally been used in alternative medicine for the prevention and treatment of diseases that afflict the general population because of their active compounds (ACs) [1, 2]. However, their importance is not only based on their pharmacological or chemotherapeutic effects but also on the possibility they offer to develop new drugs based on the structures of their components [3]. In fact, a significant number of commercial drugs have been developed directly from plants, such as quinine from Cinchona officinalis for the treatment of malaria [4], morphine from Papaver somniferum as an analgesic [5], and Taxol from Taxus brevifolia as an anticancer agent [6], among others. Therefore, countries with a great biodiversity of plants have become suitable places for the identification of new ACs with medicinal properties. Currently, Mexico ranks fifth in plant diversity and uses approximately 7000 species for medicinal purposes, although pharmacological validation has only been carried out for $5 \%$ of them [7]. Consequently, research designed to determine the efficacy of many plants that are used as alternative medicine and to evaluate their potential as a source of new ACs with therapeutic activity is important [8]. Rhus trilobata Nutt. (RHTR) is a plant of the state of Chihuahua in Mexico, which has been used for the treatment of gastrointestinal diseases and cancer. Scientific information about RHTR medicinal use and possible pharmacological properties is scarce. Currently, phytochemical constituents of the sumac RHTR have not been fully investigated. Abbott et al., (1966) showed the antineoplastic activity of extracts elaborated by the maceration of leaves with $\mathrm{EtOH}$ : $\mathrm{CHCl} 3(1: 1)(100 \mathrm{mg} / \mathrm{kg})$ and by the decoction of fruits in water $(400 \mathrm{mg} / \mathrm{kg})$, when administered intraperitoneally (i.p.) as a fixed dose for 7 days to Syrian hamsters xenotransplanted with human duodenum adenocarcinoma cells. In both cases, a 33\% reduction in the weight of the tumors was observed with respect to the control condition without treatment [9].

Later, Pettit et al. (1974) were able to isolate gallic acid and ethyl gallate from a 50\% ethanolic extract of RHTR leaves by column chromatography. Then, using the human nasopharyngeal adenocarcinoma cell line $\mathrm{KB}$, they evaluated the biological activities of these extracts in vitro, which presented an $\mathrm{IC}_{50}$ of 3.1 and $18 \mu \mathrm{g} / \mathrm{mL}$, respectively, from which they assigned cytotoxic activity of the plant to both compounds [10]. The results obtained by different research groups have demonstrated the presence of compounds with antineoplastic activity in other species of the Rhus genus, such as protocatechuic acid, fustin, fisetin, sulfuretin, and butein in $R$. verniciflua [11] and heptadecatrienylhydroquinone derivates in $R$. succedanea [12]. In addition, other polyphenols with antioxidant activity have been identified, such as garbanzol, quercetin, gallic acid and amentoflavone, which have been shown to have wide applications in health by combating processes associated with oxidative stress, such as cardiovascular and neurodegenerative diseases and cancer [13]. Therefore, it is possible that the cytotoxic activity observed in RHTR is due to the presence of other compounds that are distinct from gallates. Despite these beneficial compounds, some studies performed with $R$. toxicodendron, $R$. radicans, and $R$. diversiloba have demonstrated that the resin secreted by these plants can generate contact dermatitis when applied to the skin due to the presence of the urushiol compound, which can cause death in people who are sensitive to its effects [14-16]. Despite a dearth of studies in which animal models have been used to analyze the antineoplastic activity of RHTR $[9,10]$, the toxic and/or biochemical effects of the extracts in animal models have not been reported. Thus, additional toxicological studies are required to examine the different Rhus species to validate their therapeutic use.

Therefore, the aim of this study was to determine the biological activity of RHTR in colorectal adenocarcinoma cells to demonstrate the antineoplastic activity of the aqueous extract of the plant or its flavonoid fraction, as well as to evaluate the toxicological effect of RHTR in a murine model and, finally, the phytochemical composition of RHTR to corroborate its medicinal properties.

\section{Methods}

\section{Plant material}

The stems of Rhus trilobata Nutt. (Anacardiaceae) were collected from Cerro Pelón, Municipality of Namiquipa (Chihuahua, Mexico) (INEGI topographic map H13C42 and geographical GPS coordinates: $29^{\circ} 5^{\prime} 59^{\prime \prime} \mathrm{N}, 107^{\circ} 32^{\prime}$ $33^{\prime \prime} \mathrm{W}$ to 1960 m.a.s.l.), in May 2014, at the beginning of the spring season according to the popular use of the plant; no complete specimens and/or roots were collected to allow regeneration. The collected material was transported to the laboratory protected from light; leaves and fruits were removed. Stems were washed with tap water, dried for $48 \mathrm{~h}$ at room temperature, and milled to a sieving size of $0.5 \mathrm{~mm}$; finally, the stems were lyophilized. Features found in RHTR that allowed its identification were the presence of trifoliate leaves, pinnately composed, serrated edges and evidently cleaved, as well as the presence of small, spherical, reddish, fleshy fruits with a characteristic sour taste (Fig. 1) [17, 18]. The above features correspond to those described in the herbarium G.B. Hinton (No. 18713), found online at the Irekani, property of Unidad de Informática para la Biodiversidad (UNIBIO) from Instituto de Biología-UNAM [19], as well as in the virtual herbarium CONABIO (No. 


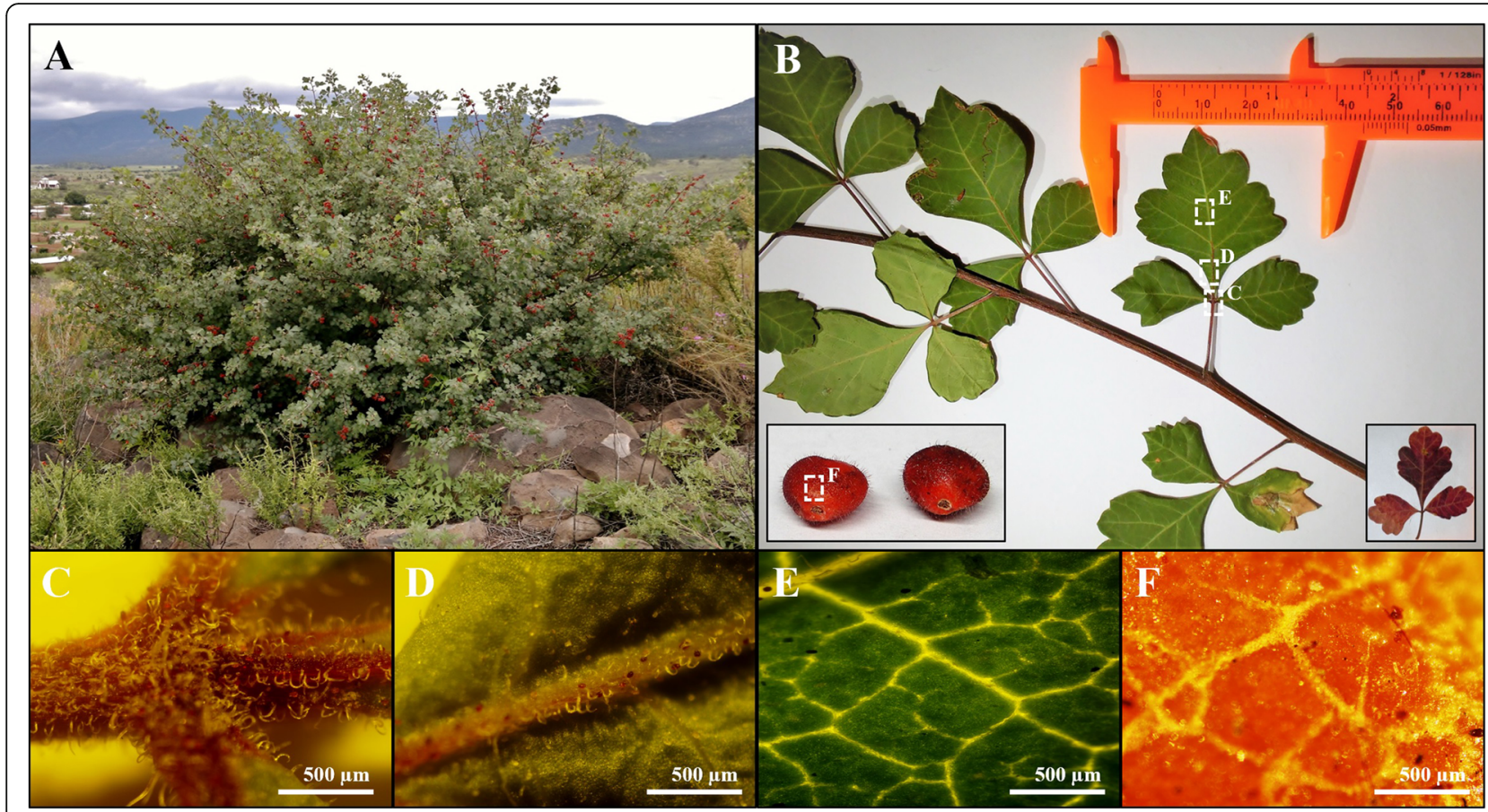

Fig. 1 Morphological characteristics of RHTR. Representative characteristics of specimens collected from the Cerro Pelón in Namiquipa Township (Chihuahua, México) in May 2014 (a). Trifoliate leaves, pinnately composed, serrated edges and evidently split, with a red-orange color in the autumn season were observed, and equally, small fruits, spherical, fleshy and reddish were found under a stereoscope at 2X magnification (b). c-f Areas analyzed by microscopy at $4 X$ magnification: adaxial face of leaves with axillary buds covered with simple trichomes (c-e) and epicarp of an irregular fruit covered with microvilli and resin (f). (Photographs are the property of Luis Varela-Rodríguez and Blanca Sánchez-Ramírez, all copyright reserved)

K000081429) where similarities in the shape and arrangements of the leaves and fruits can be seen [20]. The identification of the collected specimens was performed by Toutcha Lebgue Keleng, a Ph.D. of the Facultad de Zootecnia y Ecología from UACH. The identified specimen was validated by Dr. María de la Luz Arreguín Sánchez, herbarium curator of the Escuela Nacional de Ciencias Biológicas from IPN, and by Biol. Laura de Léon Pesqueira of the Instituto de Ciencias Biomédicas from UACJ (Voucher No. 1543).

\section{Preparation of plant extracts and fractionation}

The traditional preparation of RHTR was performed by decoction with $25 \mathrm{~g}$ of stems in $500 \mathrm{~mL}$ of boiling distilled water for $30 \mathrm{~min}$ (aqueous extract; AE). Subsequently, the $\mathrm{AE}$ was filtered and centrifuged at $2500 \mathrm{rpm}$ for $15 \mathrm{~min}$ at $4{ }^{\circ} \mathrm{C}$ in conical tubes to recover the supernatants and concentrated under negative pressure with a rotary vacuum evaporator at $40^{\circ} \mathrm{C}$ and $5 \mathrm{rpm}$ (Rotavapor ${ }^{\circledR} \mathrm{R}-300$, Büchi). Next, the $\mathrm{AE}$ was freeze-dried (FreeZone Triad, Labconco $^{\circ}$ ) and stored at $-20{ }^{\circ} \mathrm{C}$ in an amber vial. The fractionation of $\mathrm{AE}$ was performed by solid phase extraction with the aid of a vacuum Manifold (Visiprep ${ }^{\mathrm{Tm}}$, Sigma ${ }^{\circ}$ ) and $\mathrm{ENVI}^{\mathrm{TM}}-\mathrm{C}_{18}$ cartridges (Supelclean ${ }^{\mathrm{TM}}$, Sigma ${ }^{\circ}$ ) to concentrate compounds of a flavonoid nature. The cartridge was activated with $20 \mathrm{~mL}$ of $\mathrm{MeOH}$ (J.T. Baker ${ }^{\odot}$ ) and $1 \%$ acetic acid in water. Subsequently, $15 \mathrm{~mL}$ of ethyl acetate (flavonoid fraction, FF) HPLC-grade from J.T. Baker ${ }^{\bullet}$ was eluted through the cartridge and collected for concentration by rotary evaporation. Finally, the fraction was weighed and resuspended in $2 \mathrm{~mL}$ of $50 \% \mathrm{MeOH}$ (MS grade, J.T. Baker ${ }^{\oplus}$ ) and filtered with a $0.20 \mu \mathrm{m}$ PTFE syringe filter (Corning ${ }^{\odot}$ ) for storage as a stock solution in an amber vial at $-20^{\circ} \mathrm{C}$ for later use. Extracts and fractions were prepared according to the method disclosed in the Mexican patent: MX/E/2018/078316.

\section{Physicochemical analysis}

The determination of the parameters established in the quality control methodology for plant material by WHO was carried out with RHTR samples [21], as well as the quantification of primary metabolites by spectrophotometry with phenol-sulfuric acid (carbohydrates) [22], Bradford (proteins) [23] and Ruhemann (amino acids) [24] assays, respectively.

\section{Quantification of polyphenols and antioxidants}

Total phenolic content and elimination activity of free radicals in RHTR was estimated by Folin-Ciocâlteu (Sigma ${ }^{\oplus}$ ) and 2,2-diphenyl-1-picrylhydrazyl (DPPH, Sigma ${ }^{\circ}$ ) assays $[25,26]$. Additionally, flavonoids and anthocyanins were quantified using aluminum chloride $\left(\right.$ Sigma $\left.^{\circ}\right)$ and 
differential $\mathrm{pH}$ methods, respectively [27, 28]. Gallic acid $\left(\right.$ Ga, Sigma $\left.{ }^{\circ}\right)$, 6-hydroxy-2,5,7,8-tetramethylchroman-2-carboxylic acid (Trolox, Sigma ${ }^{\circ}$ ), quercetin (Que, Sigma ${ }^{\circ}$ ) or cyanidin-3-glucoside (Cya) was used as a standard compound to calculate the concentration as an equivalent. Antioxidant activity was considered high when the antioxidant efficient index (AEI) was $\geq 1$. The half antioxidant concentration $\left(\mathrm{AC}_{50}\right)$ and $\mathrm{AEI}$ were calculated according to the following formulas [29]: $A C_{50}=[($ absorbance control $-a b-$ sorbance sample $) /($ absorbance control $)] \times 100$, and $A E I=1$ $/\left(A C_{50}\right) x$ (Time $\left.A C_{50}\right)$, respectively.

\section{Cell cultures}

The cell lines used for this study were colorectal adenocarcinoma cells CACO-2 (HTB-37 $\left.{ }^{\mathrm{mt}}\right)$, Chinese hamster ovary cells CHO-K1 $\left(\mathrm{CCL}-61^{\mathrm{Tm}}\right)$ and lung/bronchus human epithelial BEAS-2B cells (CRL-9609 $9^{\mathrm{mm}}$ ) acquired from $\mathrm{ATCC}^{\circ}$. Cell monolayers were maintained in McCoy's 5A $\left(\mathrm{Gibco}^{\mathrm{Tm}}\right)$ and Dulbecco's Modified Eagle's Medium (DMEM, Gibco ${ }^{\mathrm{Tx}}$ ) supplemented with $10 \%(\mathrm{v} / \mathrm{v})$ fetal bovine serum (FBS, Gibco ${ }^{\mathrm{Tx}}$ ) thermally decomplemented, and $1 \%$ penicillin-streptomycin $(10 \mathrm{mg} / \mathrm{mL}$, Sigma $\left.{ }^{\circ}\right)$ and gentamycin $\left(10 \mu \mathrm{g} / \mathrm{mL}\right.$, Sigma $\left.{ }^{\circ}\right)$. The cells were incubated at $37{ }^{\circ} \mathrm{C}$ with $5 \% \mathrm{CO}_{2}$ (95\% humidity) and harvested using $1 \mathrm{X}$ trypsin-EDTA solution $\left(\mathrm{Sigma}^{\circ}\right)$; cell viability was determined using the Trypan blue $\left(0.4 \%\right.$ Sigma $\left.^{\circ}\right)$ exclusion assay.

\section{Biological activity of RHTR in colon cancer and normal cells}

RHTR activity in cell lines was analyzed using doseresponse viability curves with 3-(4,5-dimethylthiazol-2yl)-2,5-diphenyltetrazolium bromide (MTT, Sigma ${ }^{\circ}$ ) [30] . For this purpose, $1 \times 10^{4}$ cells were seeded in 96-well plates $\left(\right.$ Corning $\left.^{\odot}\right)$ in supplemented medium and incubated for $24 \mathrm{~h}$, at which time treatments with RHTR extract and fraction (concentrations from 5 to $1000 \mu \mathrm{g} /$ $\mathrm{mL}$ ) were added; cultures treated with vincristine, an anti-cancer drug $\left(\mathrm{Sigma}^{\circ}\right)$ or $1 \mathrm{X}$ PBS were used as positive or negative controls, respectively. Cultures were incubated for $24 \mathrm{~h}$, and $4 \mathrm{~h}$ prior to the end of the treatments, $20 \mu \mathrm{L}$ of MTT ( $5 \mathrm{mg} / \mathrm{mL}$ in $1 \mathrm{X}$ PBS, Sigma $\left.{ }^{\circ}\right)$ was added to each well. At the end of the experiment, cell lysis was conducted with acidified isopropanol (Sigma $\left.{ }^{\circ}\right)$, and the absorbance at $590 \mathrm{~nm}$ was measured using a Varioskan ${ }^{\circ}$ Flash microreader (Thermo Scientific ${ }^{\circ}$ ). The cell viability was calculated using the following formula: $\%$ Viability $=($ absorbance sample $/$ absorbance control $)$ $\times 100$. The half-maximal inhibitory concentration $\left(\mathrm{IC}_{50}\right)$ was calculated by regression analysis (percent survival vs log concentration). The biological activity in cancer cells was classified as follows [31]: high $\mathrm{IC}_{50} \leq 30 \mu \mathrm{g} / \mathrm{mL}$, medium $31-70 \mu \mathrm{g} / \mathrm{mL}$ and low $71-100 \mu \mathrm{g} / \mathrm{mL}$. Finally, for the antiproliferative assays, CACO-2 cells were treated every $24 \mathrm{~h}$ with the $\mathrm{IC}_{50}$ previously determined up to $72 \mathrm{~h}$ to determine the mitotic index (MI).

\section{Selectivity index $(S I)$ and median lethal dose ( $\left.L D_{50}\right)$}

The degree of selectivity [32] and lethal dose [33] were determined based on the $\mathrm{IC}_{50}$ obtained from in vitro anticancer and toxicological assays. The formulas applied were as follows: $S I=I C_{50}$ normal cell line / IC $C_{50}$ cancer cell line and $L D_{50}(\mathrm{oral}, \mathrm{mg} / \mathrm{kg})=10^{E X P}\left[\left(0.372 \times \log I C_{50}\right.\right.$ normal cell line) +2.024$]$.

\section{Measurement of the cell cycle}

The cell cycle and sub- $G_{1}$ distribution were determined by flow cytometry with propidium iodide staining in CACO-2 cells treated with RHTR $[2,34]$. To achieve this goal, $5 \times 10^{5}$ cells per well were seeded in a 6-well plate $\left(\right.$ Corning $\left.^{\circ}\right)$ with supplemented medium for $24 \mathrm{~h}$. The adherent cells were treated with the $\mathrm{IC}_{50}$ of samples and controls $\left(20 \mu \mathrm{g} / \mathrm{mL}\right.$ mitomycin Sigma ${ }^{\circ}$ and 1X PBS vehicle) for $24 \mathrm{~h}$. After this period, the culture medium was removed, and the cells were detached by trypsinization. Subsequently, the cells were fixed and permeabilized with $50 \% \mathrm{EtOH}$ at $-20^{\circ} \mathrm{C}$ for $12 \mathrm{~h}$. Finally, the cells were washed and pelleted by centrifugation (2000 $\mathrm{rpm}, 10 \mathrm{~min}$ and $4{ }^{\circ} \mathrm{C}$ ), followed by the addition of $400 \mu \mathrm{L} 1 \mathrm{X}$ PBS, $10 \mu \mathrm{L}$ RNAse A $\left(10 \mathrm{mg} / \mathrm{mL}\right.$, Sigma $\left.{ }^{\circ}\right)$ and $20 \mu \mathrm{L}$ propidium iodide $\left(1 \mathrm{mg} / \mathrm{mL}\right.$, Invitrogen $\left.{ }^{\circ}\right)$ for $1 \mathrm{~h}$ at $37^{\circ} \mathrm{C}$ in the dark. The relative DNA content in the cells was analyzed with a BD FACSCalibur ${ }^{\mathrm{rm}}$ (Becton Dickinson $^{\circ}$ ) based on red fluorescence, and quantitation of each cell cycle stage was performed with ModFit LT software (version 5.0, Verity Software House ${ }^{\circ}$ ).

\section{Genotoxic analysis by the comet assay}

The genotoxic activity of RHTR was evaluated with a single cell gel electrophoresis method under alkaline conditions using the CHO-K1 cell line $[35,36]$. To achieve this goal, $5 \times 10^{4}$ cells per well were seeded in a 24-well plate (Corning ${ }^{\circ}$ ) with $2 \mathrm{~mL}$ of supplemented McCoy's 5A medium for $24 \mathrm{~h}$. Adherent cells were treated with the $\mathrm{IC}_{50}$ of samples and controls $\left(0.3 \% \quad \mathrm{H}_{2} \mathrm{O}_{2}\right.$ Sigma $^{\circ}$ and $1 \mathrm{X}$ PBS vehicle) for $24 \mathrm{~h}$, the culture medium was removed, the cell monolayer was washed with $1 \mathrm{X}$ PBS and the cells were detached by trypsinization. After centrifugation, the cells were mixed with $1 \%$ low melting point agarose $\left(\right.$ Sigma $\left.^{\circ}\right)$ and rapidly spread onto a microscope slide that had been precoated with $0.5 \%$ normal melting point agarose $\left(\right.$ Sigma $\left.^{\circ}\right)$. To stain nucleic acids, SYTOX $^{\circ}$ green $\left(5 \mathrm{mM}\right.$, Thermo Scientific $\left.{ }^{\circ}\right)$ at a 1:5000 dilution $(v / v)$ was added to the buffers. The slides were coverslipped and allowed to jellify. Later, the coverslips were placed in ice-cold lysis buffer $(2.5 \mathrm{M}$ $\mathrm{NaCl}, 100 \mathrm{mM}$ EDTA, $10 \mathrm{mM}$ Tris-base, 10\% DMSO and $1 \%$ Triton X-100 of Sigma ${ }^{\circ}, \mathrm{pH} 10$ ) for $1 \mathrm{~h}$ at $4{ }^{\circ} \mathrm{C}$. 
After lysis, the slides were placed in a horizontal electrophoresis chamber with alkaline buffer $(1 \mathrm{mM}$ EDTA and $300 \mathrm{mM} \mathrm{NaOH}$ of Sigma $\left.{ }^{\circ}, \mathrm{pH} 13\right)$ for $30 \mathrm{~min}$ at $4{ }^{\circ} \mathrm{C}$ in the dark to allow DNA unwinding. Electrophoresis was carried out for $20 \mathrm{~min}$ at $25 \mathrm{~V}$ and $300 \mathrm{~mA}$, and the slides were then immersed in neutralization buffer $(0.4$ $\mathrm{M}$ Tris- $\left.\mathrm{HCl} \mathrm{Sigma}{ }^{\circ}, \mathrm{pH} 7.5\right)$ for $15 \mathrm{~min}$ at $25^{\circ} \mathrm{C}$ and fixed with $2 \mathrm{~mL}$ absolute $\mathrm{EtOH}$ (J.T.Baker ${ }^{\circ}$ ) for $10 \mathrm{~min}$ in the dark. Finally, the preparations were mounted with Vectashield $^{\oplus}$ medium (Vector Laboratories ${ }^{\circ}$ ), and the length of damaged DNA migration was analyzed and measured by confocal microscopy (LSM 700, Zeiss ${ }^{\circ}$ ) using ZEN 2011 software (version 1.0, Zeiss ${ }^{\circ}$ ). The genotoxic activity was classified as high if $40-95 \%$ of the cells showed damaged DNA, medium if $10-40 \%$ of them had damaged DNA, low when 5-10\%, and null when less than $5 \%$ had damaged DNA.

\section{ROS-intracellular quantification by $\mathrm{CM}-\mathrm{H}_{2} \mathrm{DCFDA}$}

The production of intracellular reactive oxygen species (ROS) was determined with the chemical reporter (5-(and6)-chloromethyl-2',7'-dichlorodihydrofluorescein diacetate (CM- $\left.\mathrm{H}_{2} \mathrm{DCFDA}\right)$ in CHO-K1 cells treated with RHTR [37]. To achieve this goal, $1 \times 10^{4}$ cells per well were seeded in 96-well plates (Corning ${ }^{\circ}$ ) with $200 \mu \mathrm{L}$ of supplemented McCoy's $5 \mathrm{~A}$ medium for $24 \mathrm{~h}$. The adherent cells were treated with the $\mathrm{IC}_{50}$ of samples and controls $\left(0.3 \% \mathrm{H}_{2} \mathrm{O}_{2}\right.$, Sigma ${ }^{\circ}$ and $1 \mathrm{X}$ PBS vehicle) for $24 \mathrm{~h}$. After this period, the culture medium was removed, and $25 \mu \mathrm{M} \quad \mathrm{CM}-\mathrm{H}_{2}$ DCFDA (Thermo Scientific ${ }^{\circ}$ ) was added for $30 \mathrm{~min}$ at $37^{\circ} \mathrm{C}$. Finally, the fluorescence was quantified at $\lambda_{\mathrm{ex}} 495$ (9 bandwidth) / $\lambda_{\text {em }} 530$ (20 bandwidth) $\mathrm{nm}$ in a Varioskan Flash microreader (Thermo Scientific ${ }^{\circ}$ ) and corroborated by confocal microscopy (LSM 700, Zeiss ${ }^{\circ}$.

\section{Evaluation of morphology and cell death}

Adherent cultures plated at $3 \times 10^{4}$ cells per well in LabTek $^{\mathrm{Tt}}$ chamber slides (Thermo Scientific ${ }^{\circ}$ ) were treated with the $\mathrm{IC}_{50}$ of samples and controls $(25 \mu \mathrm{g} / \mathrm{mL}$ vincristine Sigma ${ }^{\circ}$ and $1 \mathrm{X}$ PBS vehicle) for $24 \mathrm{~h}$. Then, the culture medium was removed, and the cells were fixed with $4 \%$ paraformaldehyde $\left(\right.$ Sigma $\left.{ }^{\circ}\right)$ for $1 \mathrm{~h}$ at $37^{\circ} \mathrm{C}$. The cells were then washed with $1 \mathrm{X}$ PBS and stained. The morphology of the cells was determined using Hemacolor ${ }^{\circ}$ rapid staining $\left(\mathrm{Merck}^{\circ}\right)$, and the presence of apoptosis was assessed using the Apo-BrdU ${ }^{\mathrm{Tm}}$ TUNEL assay kit with Alexa Fluor 488 (Invitrogen $^{\circ}$ ), according to the manufacturer's instructions. After applying both stains, the slides were treated with Vectashield ${ }^{\circ} /$ DAPI mounting medium (Vector Laboratories ${ }^{\circ}$ ) or Entellan $^{\circ}$ resin $\left(\right.$ Merck $\left.^{\circ}\right)$ according to the assay and analyzed by optical microscopy (BX41, Olympus ${ }^{\circ}$ ) or confocal microscopy (LSM 700, Zeiss ${ }^{\circ}$ ) using a 40X immersion lens with
Image-Pro Plus (version 4.0, Media Cybernetics $\odot$ ) or ZEN 2011 (version 1.0, Zeiss ${ }^{\circ}$ ) software.

\section{Experimental animals}

According to the recommendations of OECD [38], 30 adult female $B A L B / c$ mice with a body weight of $25 \pm 5$ $\mathrm{g}$ and aged 6 to 8 weeks were obtained from the Bioterium of the Facultad de Ciencias Químicas, UACH (Additional file 1: Figure S1A). This study was carried out in accordance with Official Mexican Regulations [39] and approved by an Ethics Committee (Authorization No. 0010/11).

\section{Acute toxicity studies}

The toxicological effects of RHTR were determined in the mouse animal model using Guideline 425 by OECD with some modifications [40]. For this purpose, female $B A L B / c$ mice were randomly divided into two studies with three groups each (5 animals per group) (Additional file 1: Figure S1B). Subsequently, a single dose of $200 \mathrm{mg} / \mathrm{kg}$ body weight of sample and $100 \mu \mathrm{L}$ of vehicle (1X PBS) was administered by the intraperitoneal route (i.p.) (Additional file 1: Figure S1C); three groups of animals were sacrificed after $24 \mathrm{~h}$ (Study 1), and the other three groups were sacrificed after 14 days (Study 2, Additional file 1: Figure S1). Animals were observed at 1, 2, 4 and $6 \mathrm{~h}$ posttreatment to detect any signs of toxicity and/or death at $24 \mathrm{~h}$ (Additional file 1: Figure S1D). Mice were fasted for $8 \mathrm{~h}$ before finishing the assay to avoid biochemical alterations due to food, but access to water was maintained ad libitum (Additional file 1: Figure S1E). The $\mathrm{LD}_{50}<200 \mathrm{mg} / \mathrm{kg}$ was considered when 3 individuals died in a group and the $\mathrm{LD}_{50}>200 \mathrm{mg} / \mathrm{kg}$ when one or none of the individuals died (Additional file 1: Figure S1F). The weight of the mice was determined using an electronic bascule (CS200, Ohaus ${ }^{\circ}$ ) at the beginning and end of the treatments. The \% body weight change (\% BWC) and body mass index (BMI) were calculated as follows [41]: \% $B W C=$ [(final weight - initial weight) / initial weight] $\times 100$ and $B M I=$ weight $(g)$ / length of nose until rear foot $(\mathrm{cm})^{2}$. After the evaluation time, the surviving animals were anesthetized by i.p. injection with $250 \mu \mathrm{L}$ of diluted sodium pentobarbital 1:10 $(v / v)\left(6.3 \mathrm{~g} / 100 \mathrm{~mL}\right.$, Pet's Pharma $\left.^{\circ}\right)$ using an insulin syringe and $25 \mathrm{G}$ needle for the subsequent analysis (Additional file 1: Figure S1G).

\section{Determination of biochemical parameters and hematic biometry}

Peripheral blood samples were obtained by retro-orbital bleeding of anaesthetized animals using capillary tubes and $\mathrm{BD}$ Microtainer tubes with $\mathrm{K}_{2}$ EDTA (for cell counts) without anticoagulant (to obtain serum for biochemical determinations) (Additional file 1: Figure S1H). 
Hematic biometry was performed using the hematology autoanalyzer system (BC-2300, Mindray $\left.{ }^{\oplus}\right)$ and the biochemical parameters with the standard diagnostic test (Human ${ }^{\odot}$ kits) with an automated medical system (Prestige ${ }^{\circledast}$ 24i, Tokyo Boeki ${ }^{\oplus}$ ).

\section{Anatomical and histological assessments}

After blood samples were obtained, mice were sacrificed by cervical fracture and mounted on a dissecting board for necropsy. A complete mid-laparotomy was performed, and lungs, spleen, heart, liver and kidneys were dissected for anatomical observations (Additional file 1: Figure S1I). Adhesions and/or connective tissue in organs were eliminated; organs were measured using a digital Vernier caliper (Truper $\left.{ }^{\oplus}\right)$, weighed, and photographed. The relative organ weight expressed as percentage $(\%$ ROW $)$ was calculated as follows: \% $R O W=[($ organ weight / body weight mouse $) \times 100]$. Finally, organs were fixed in $4 \%$ paraformaldehyde $\left(\right.$ Sigma $\left.{ }^{\odot}\right)$ and embedded in paraffin to obtain 5 - $\mu$ m-thick sections. Tissue slices were stained with hematoxylineosin $\left(\mathrm{Merck}^{\odot}\right)$ to perform the microscopic analysis searching for pathological lesions by optical microscopy (BX41, Olympus ${ }^{\oplus}$ ) with 10X and 40X objectives.

\section{Phytochemical characterization of RHTR by UPLC-MS ${ }^{\mathrm{E}}$}

The identification of compounds in RHTR sumac was performed by UPLC (Acquity ${ }^{\mathrm{TM}}$ series, Waters ${ }^{\oplus}$ ) with a photodiode array detector (PAD) and coupled to MS $\left(\right.$ Synapt $^{\mathrm{Tm}}$ G1, Waters $\left.{ }^{\circledR}\right)$. The instrument was equipped with an Acquity ${ }^{\mathrm{Tm}}$ UPLC CSH C ${ }_{18}$ column $(2.1 \mathrm{~mm} \times 150$ $\mathrm{mm}, 1.7 \mu \mathrm{m}$, Waters ${ }^{\oplus}$ ); the mobile phase used was MilliQ purified water (solvent A) (Simplicity ${ }^{\odot}$ UV, Millipore ${ }^{\circ}$ ) and acetonitrile (solvent B) (J.T.Baker ${ }^{\circ}$ ) (both acidified with $0.1 \%$ formic acid, $v / v$ ) MS-grade. The solvents were degassed by sonication in an ultrasonic bath (Branson 1800 Emerson $\left.^{\mathrm{TM}}\right)$. The compounds were eluted via a gradient separation in reversed-phase as follows: $0 \mathrm{~min}, 5 \%$ B; $0.5 \mathrm{~min}, 5 \% \mathrm{~B} ; 20 \mathrm{~min}, 75 \% \mathrm{~B} ; 25 \mathrm{~min}, 75 \% \mathrm{~B} ; 25.5$ min, 90\% B and holding for 2 minutes for column washing; $27.6 \mathrm{~min}, 5 \% \mathrm{~B}$ and holding for $4.4 \mathrm{~min}$ for column re-equilibration. Samples $(1 \mathrm{mg} / \mathrm{mL})$ were filtered with a $0.20-\mu \mathrm{m}$ PTFE syringe filter (Captiva Econo Filter, Agilent ${ }^{\circ}$ ) and maintained at $4{ }^{\circ} \mathrm{C}$ during the assay. The chromatographic conditions were as follows: the flow rate was set at $0.2 \mathrm{~mL} / \mathrm{min}$ throughout the gradient from the UPLC system into the MS detector; the injection volume was $10 \mu \mathrm{L}$; and the column temperature was maintained at $30^{\circ} \mathrm{C}$. The samples were analyzed by PAD at $280 \mathrm{~nm}$ and ions generated by the electrospray ionization source (ESI) in negative and positive mode. Spectra were acquired over a mass range from 50 to $1500 \mathrm{~m} / z$ using the $M S^{\mathrm{E}}$ acquisition mode. The precursor ion collision energy was set to $6 \mathrm{eV}$ (trap section) and 20 to $40 \mathrm{eV}$ in the transfer section. The optimum values of the ESI-MS parameters were as follows: capillary voltage, $3.0 \mathrm{kV}$; sampling cone, $35.0 \mathrm{~V}$; extraction cone, $4.0 \mathrm{~V}$; source and desolvation temperature, $150{ }^{\circ} \mathrm{C}$ and $350{ }^{\circ} \mathrm{C}$; cone and desolvation gas flow, $20.0 \mathrm{~L} / \mathrm{h}$ and $600 \mathrm{~L} / \mathrm{h}$, respectively. During acquisition, leucine enkephalin was used as the mass reference $\left(556.2771, \mathrm{M}+\mathrm{H}^{+}\right)$, which was infused directly at a flow of $5 \mu \mathrm{L} / \mathrm{min}$ at a concentration of $2 \mathrm{ng} /$ $\mathrm{mL}$, allowing internal mass calibration. MS data were acquired in continuum mode and processed with MassLynx $^{\oplus}$ (version 4.1 , Waters ${ }^{\oplus}$ ), and the compounds were putatively identified with Progenesis ${ }^{\circ}$ QI for small molecules (Nonlinear Dynamics version 2.3, Waters ${ }^{\odot}$ ) using Chemspider and Progenesis MetaScope as identification methods. The search parameters were as follows: precursor tolerance of $30 \mathrm{ppm}$, theoretical fragmentation and fragment tolerance of $30 \mathrm{ppm}$, with an isotope similarity filter of $90 \%$. The databases consulted were AraCyc, PlantCyc, KEGG and HMDB. Compounds such as gallic acid, methyl gallate, quercetin, quercitrin, myricetin, and fisetin were confirmed by comparing their retention times and MS/MS fragmentation patterns with analytical standards.

\section{Statistical analysis}

The results are presented as the mean \pm standard deviation (S.D.) of values obtained in three independent experiments performed in triplicate. The statistical analysis was conducted using one-way ANOVA for parametric data with a normal distribution, employing Minitab ${ }^{\circ}$ software (version 16.1) and with Tukey's and Dunnett's tests for comparisons. The differences between the means among different treatments were considered to be significant when $p \leq 0.05$.

\section{Results}

\section{Physicochemical analysis of RHTR}

Physicochemical parameters measured in RHTR stems are shown in Table 1; moisture and ash contents were within normal limits established by the WHO for the storage and use of medicinal plants [21]. The AE had more carbohydrates than other components such as proteins, amino acids or lipids. Differences in the concentration of primary metabolites among the analyzed samples were due to changes in the metabolic activity of RHTR, by its maturation process, regrowth or stress factors such as drought and temperature changes [42].

\section{Contents of polyphenols and antioxidants in $\mathrm{AE}$ and $\mathrm{FF}$ from RHTR}

It has been reported in the literature, at least for $R$. verniciflua, $R$. succedanea and $R$. coriaria, that these species contain a high concentration of phenolic compounds, such as gallates and flavonoids with antioxidant, anti- 
Table 1 Physicochemical analysis of RHTR as a quality control

\begin{tabular}{ll}
\hline Composition & Quantity \\
\hline Carbohydrates & $309.3 \pm 27.5$ \\
Amino acids & $15.9 \pm 3.7$ \\
Proteins & $21.1 \pm 3.3$ \\
Lipids & $4.5 \times 10^{-4} \pm 2.1 \times 10^{-4}$ \\
$\%$ Humidity & $7.9 \pm 2.1$ \\
\% Total ash & $3.5 \pm 0.04$ \\
\% Soluble ash $\mathrm{H}_{2} \mathrm{O}$ & $2.8 \pm 0.5$ \\
$\%$ Insoluble ash $\mathrm{HCl}$ & $1.0 \pm 0.5$ \\
pH & $4.4 \pm 0.3$ \\
\hline
\end{tabular}

The results $(\mathrm{mg} / \mathrm{g})$ show the mean \pm S.D. of three biological replicates $(n=3$, in triplicate)

inflammatory, antibacterial, antiparasitic, and antitumoral activities. [13]. Therefore, the AE-RHTR was fractionated to concentrate these compounds. The $\mathrm{AE}$ showed the highest concentration of polyphenols $(94.14 \pm 7.8 \mathrm{mg} / \mathrm{g}$ GAE), flavonoids $(84.56 \pm 3.6 \mathrm{mg} / \mathrm{g}$ $\mathrm{QE})$, anthocyanins $(9.98 \pm 1.5 \mathrm{mg} / \mathrm{g}$ Cyd-3-Glu-E) and antioxidants $(197.5 \pm 11.3 \mathrm{mg} / \mathrm{g} \mathrm{TE}$, very high activity) compared to FF (Table 2). Additionally, AE showed a DPPH inhibition of $86.07 \%$ (highest activity) in contrast to the low activity of FF with only $14.10 \%$ inhibition; AEI could not be calculated because the samples did not reach the $\mathrm{AC}_{50}$ needed to inhibit only half of DPPH in the formula (Table 2). These results are apparently related to the yield or efficiency obtained from the fractionation of RHTR, whereby the FF presented lower concentrations than those in the AE. However, the values obtained in AE-RHTR were similar to those reported for green tea [43] and other Rhus sp. [12], which have been characterized as having high concentrations of these compounds. Carcinogenesis studies in cell lines

Table 2 Contents of polyphenols and antioxidants in RHTR

\begin{tabular}{lll}
\hline Samples & AE & FF \\
\hline Weight (mg) & $590 \pm 49.5$ & $22 \pm 4.9$ \\
Polyphenols (Ga Eq) & $94.14 \pm 7.8$ & $16.38 \pm 3.8$ \\
Flavonoids (Que Eq) & $84.56 \pm 3.6$ & $27.4 \pm 5.7$ \\
Anthocyanins (Cya Eq) & $9.98 \pm 1.5$ & $0.043 \pm 0.01$ \\
Antioxidants (Trolox Eq) & $197.5 \pm 11.3$ & $13.2 \pm 0.09$ \\
AC $_{50}$ & 0.042 & 0.105 \\
$\mathrm{~T}_{\text {AC50 }}$ & 1 & 41 \\
\% DPPH Inhibition & 86.07 & 14.10 \\
AEl & ND & ND \\
Antioxidant activity & Very high & Low \\
\hline
\end{tabular}

The results $(\mathrm{mg} / \mathrm{g})$ show the mean \pm S.D. of three biological replicates $(n=3$, in triplicate). DPPH 2,2 diphenyl-1-picrylhydrazyl, $N D$ not determined, Ga gallic acid, Que. quercetin, Cya cyanidin-3-glucoside, $E q$ equivalents, $A C_{50}$ half antioxidant concentration $(\mathrm{mg} / \mathrm{mL}), T_{A C 50}$ time in which $\mathrm{AC}_{50}$ was observed (min), $A E I$ antioxidant efficient index, $A E$ aqueous extract, $F F$ flavonoid fraction and animal models have shown that plant extracts with abundant polyphenols can inhibit tumorigenesis during the initiation, promotion and progression stages through their anti/pro-oxidant effects [44], whereby the biological activity of RHTR was evaluated.

\section{Biological activity of AE and FF from RHTR in cancer and normal cells}

Several studies have linked the anti/pro-oxidant activity of plants with their antineoplastic effect. Consequently, in this study the biological activity of RHTR was evaluated against colon adenocarcinoma cells (CACO-2). The $\mathrm{IC}_{50}$ of treatments with $\mathrm{AE}$ and $\mathrm{FF}$ at $24 \mathrm{~h}$ in CACO-2 cells was 5 and $18 \mu \mathrm{g} / \mathrm{mL}$, respectively ( $p \leq 0.05$, Dunnett) (Table 3 ). Both samples, demonstrated biological activity below $100 \mu \mathrm{g} / \mathrm{mL}$ in accordance with the U.S. National Cancer Institute (NCI) guidelines for new therapeutic candidates against cancer [31, 45]. Subsequently, the $\mathrm{IC}_{50}$ doses calculated previously were used to evaluate their antiproliferative activity in assays from 24 to $72 \mathrm{~h}$ in CACO-2 cells (Fig. 2a). The statistical analysis showed that all treatments were effective compared with cells treated with $1 \mathrm{X}$ PBS at different times ( $p \leq 0.05$, Dunnett). Moreover, $\mathrm{AE}$ and $\mathrm{FF}$ showed no differences from the vincristine dose formerly determined ( $\mathrm{IC}_{50}$ : $25 \mu \mathrm{g} / \mathrm{mL}$, Table 3) ( $p>0.05$, ANOVA). The morphology and apoptosis assays used to expose cellular damage in CACO-2 revealed that cells treated with $\mathrm{AE}$ and $\mathrm{FF}$ had a typical morphology with respect to the control group (1X PBS), but with a considerable increase in cytoplasmic vesicles and absence of mitotic division, suggesting a quiescent/cytostatic effect (Fig. 2b). In addition, the TUNEL assay demonstrated nuclear DNA fragmentation in $7.85 \pm 1.4 \%$ of the cells treated with $\mathrm{AE}$ and $11.6 \pm 4.8 \%$ of the cells treated with $\mathrm{FF}$ due to the activation of an apoptotic process $(p \leq 0.05$, ANOVA) (Fig. 2b). The determination of the cell cycle during each treatment with $\mathrm{AE}$ and $\mathrm{FF}$ showed $78.5 \pm 3.1 \%$ and $73.5 \pm 2.2 \%$ arrest at $G_{1}$ phase, respectively ( $p \leq 0.05$, ANOVA), as well as the presence of a sub- $\mathrm{G}_{1}$ population of $4.9 \pm 1.7 \%$ and $10.2 \pm 1 \%$ related to the apoptotic processes (Fig. 2c). In dot-plot graphs, an increase in cellular granularity was observed for all treatments with respect to the 1X PBS control group (Fig. 2c). These results correlated and demonstrated that the main effect of RHTR was the arrest of the cell cycle and the subsequent induction of cell death by apoptosis in cancer cells. The in vitro toxicological assays in ovarian (CHO-K1) and lung/bronchus (BEAS-2B) epithelial cells revealed that $\mathrm{AE}$ had a lethal effect at $600 / 800 \mu \mathrm{g} / \mathrm{mL}$ respectively, while FF was toxic at $600 \mu \mathrm{g} / \mathrm{mL}$ (Table 3), reducing the cellular viability compared with the control group 
Table 3 Biological activity of RHTR in cell lines and BALB/C mice

\begin{tabular}{|c|c|c|c|c|}
\hline & $\mathrm{AE}$ & $\mathrm{FF}$ & Vincristine & IX PBS \\
\hline Cells & \multicolumn{4}{|c|}{ In vitro studies: $I C_{50}, \mathrm{SI}$ and $L D_{50}$} \\
\hline $\mathrm{IC}_{50}$ CACO-2 & 5 (High) & 18 (High) & 25 (High) & $>800$ (Very low) \\
\hline $\mathrm{IC}_{50} \mathrm{BEAS}-2 \mathrm{~B}$ & 800 (Very low) & 600 (Very low) & 25 (High) & $>800$ (Very low) \\
\hline $\mathrm{IC}_{50} \mathrm{CHO}-\mathrm{K} 1$ & 600 (Very low) & 600 (Very low) & 57 (medium) & $>800$ (Very low) \\
\hline $\mathrm{SI}$ & $140+++$ & $33.3++$ & $1.64+$ & ND \\
\hline \multirow[t]{2}{*}{ LD $_{50}$ [Theoretical] } & 1141.5 & 1209 & 350 & ND \\
\hline & \multicolumn{4}{|c|}{ In vivo studies: acute toxicity } \\
\hline Sign toxicity & None & None & ND & None \\
\hline Survivors (\%) & 100 & 100 & ND & 100 \\
\hline Final weight (g) & $28.6 \pm 2.4$ & $28.2 \pm 2.4$ & ND & $26.5 \pm 2.3$ \\
\hline
\end{tabular}

The results show the mean \pm S.D. of three biological replicates $(n=3$, in triplicate)

The values in parentheses correspond to the biological activity of the samples

Selective index (SI) indicate specific activity on cancer cells vs normal cells $(+++$, very high; ++ , high; + , low)

$N D$ not determined, $I C_{50}$ half-maximal inhibitory concentration $(\mu \mathrm{g} / \mathrm{mL}), L D_{50}$ median lethal dose (oral, $\mathrm{mg} / \mathrm{kg}$ ), $A E$ aqueous extract, $F F$ flavonoid fraction

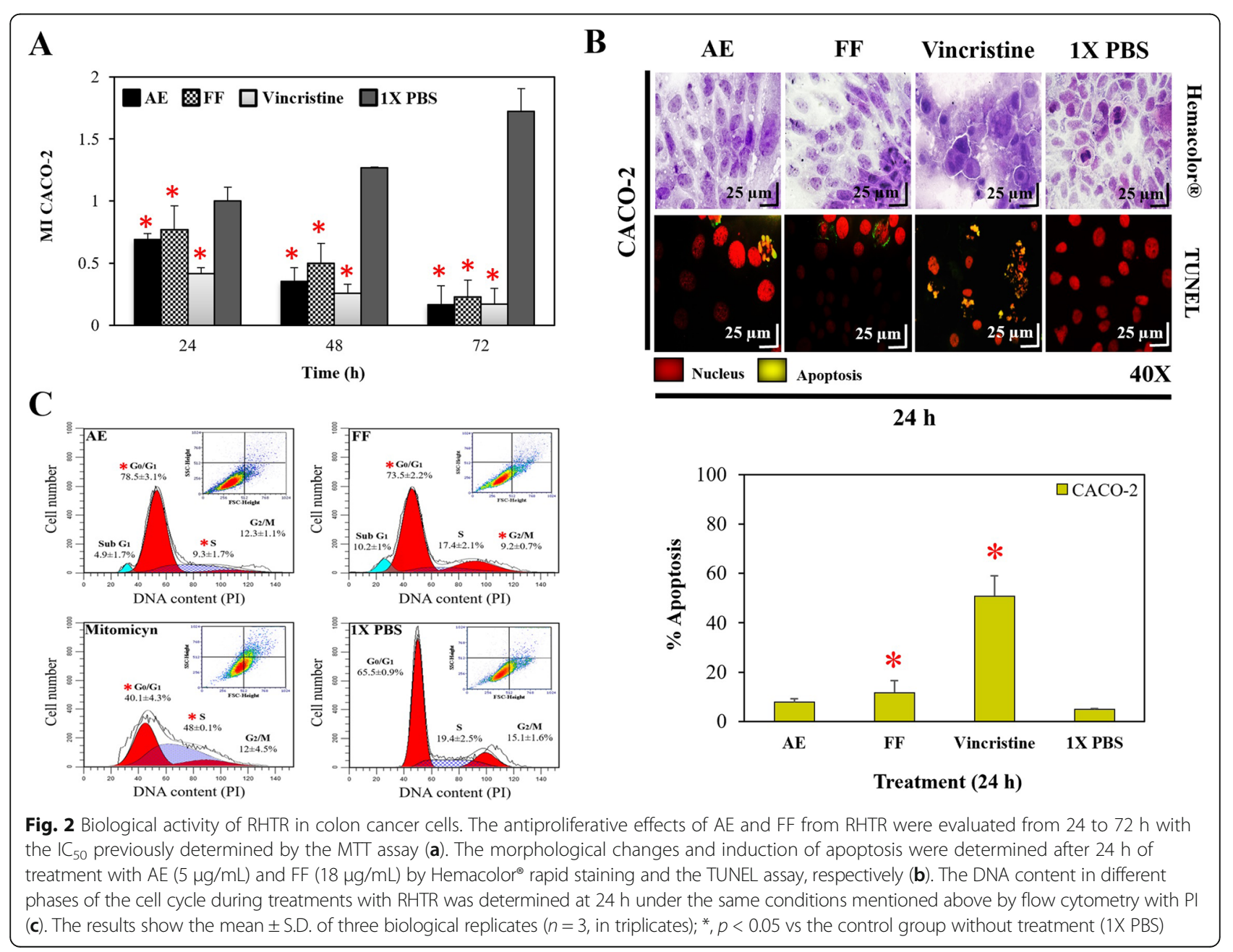




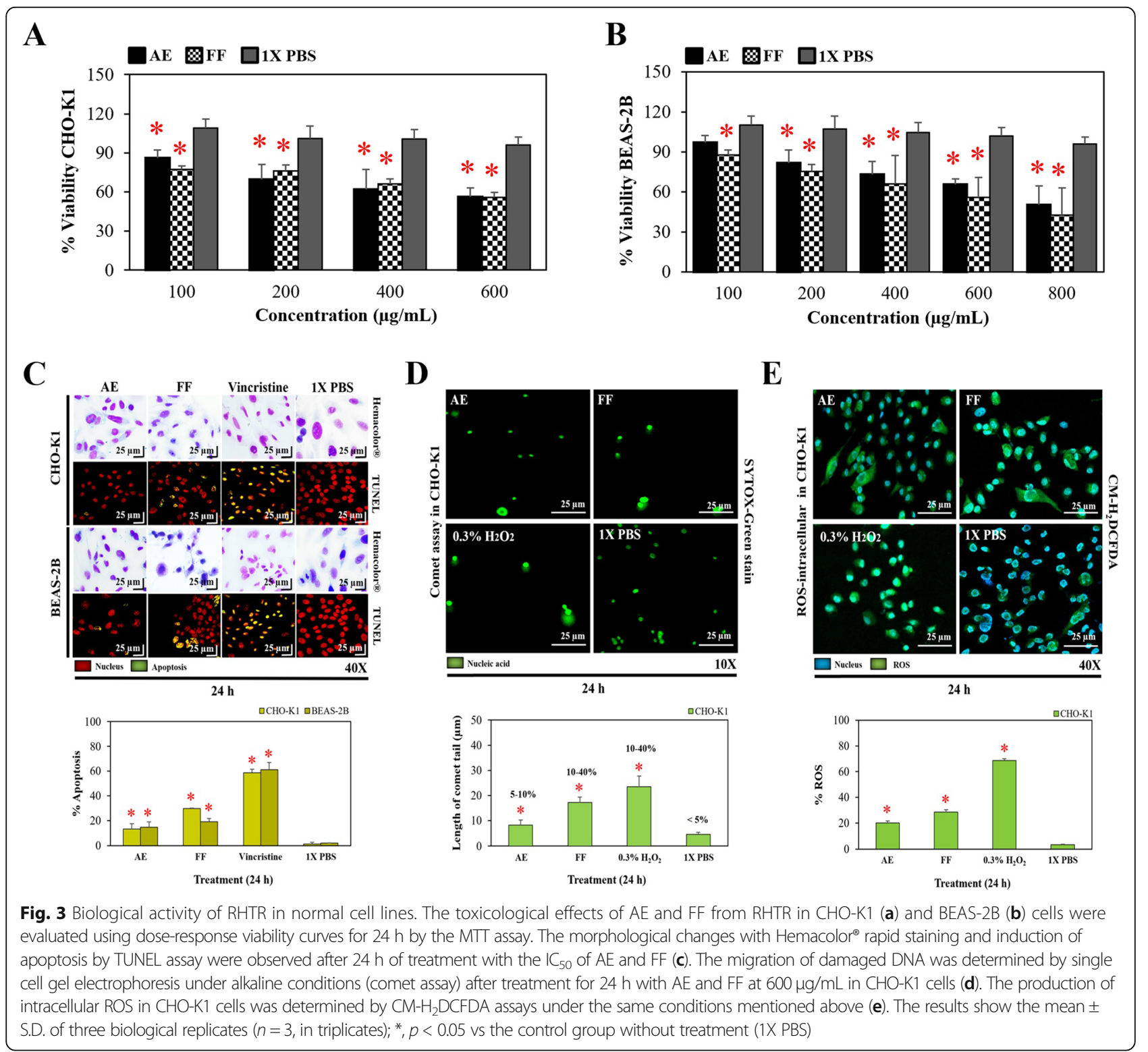

$(p \leq 0.05$, Dunnett) (Fig. 3a and b). Morphological and TUNEL analyses demonstrated changes in the cells as a consequence of the administration of $\mathrm{AE}$ and $\mathrm{FF}$ at the above mentioned concentrations (Fig. 3c), among which a decrease in cellular cytoplasm, condensation of chromatin, loss of cellular contact, and absence of mitotic division were evident, as well as nuclear DNA fragmentation in $13 \pm 4.3 / 14.7 \pm 4.1 \%$ of the cells treated with $\mathrm{AE}$ and $29.6 \pm 0.6 / 19.1 \pm 2.4 \%$ of the cells treated with FF ( $p \leq 0.05$, ANOVA), respectively; all these alterations together demonstrated cell death by apoptosis. The comet assay and ROS determination in CHO-K1 cells showed that treatments with $\mathrm{AE}$ and $\mathrm{FF}$ induced a genotoxic effect that may have been due to the production of intracellular ROS; with DNA damage of $8.2 \pm 1.9 \%$ (low effect) and $17.1 \pm$ $2.1 \%$ (medium effect) according to the comet tail length, and ROS of $19.9 \pm 1.6 \%$ and $28.5 \pm 1.9 \%$, respectively ( $p \leq 0.05$, ANOVA) (Fig. $3 \mathrm{~d}$ and e). These results correlate with a highly selective effect of RHTR observed on cancer cells vs normal cells because AE had an SI of 144 (very high), while the FF was 33.3 (high) compared with that of the vincristine control, which had a low SI of 1.6 (Table 3), revealing that RHTR could become an important tool for the prevention and elimination of cancer; however, more in-depth studies are needed to support this hypothesis. 


\section{Acute toxicity evaluation in $B A L B / c$ mice with $A E$ and $F F$} from RHTR

After i.p. administration of $\mathrm{AE}$ and $\mathrm{FF}$ at $200 \mathrm{mg} / \mathrm{kg}$ using the "up-and-down" method, no behavioral changes (agitation, tremor, drowsiness, loss of appetite) or signs of toxicity (dyspnea, photophobia, blindness, diarrhea, heart failure, muscle weakness, seizures, epithelial pigmentation) were observed in rodents during the initial hours or after $24 \mathrm{~h}$ of treatment. The assay was extended for 14 days to determine the number of surviving animals, which was $100 \%$ in both cases and to calculate the $\mathrm{LD}_{50}$ for $\mathrm{AE}(1141 \mathrm{mg} / \mathrm{kg})$ and for $\mathrm{FF}(1209 \mathrm{mg} / \mathrm{kg})$, respectively (Table 3 ). The mice did not present significant changes in body weight compared with the control group ( $p \leq 0.05$, ANOVA), resulting in a weight gain and BMI of $9.5 \%(5.20 \pm 0.43)$ for $\mathrm{AE}$ and $11.2 \%(4.5 \pm 0.19)$ for $\mathrm{FF}$, with the latter being higher than the control group, which was $10.1 \%(4.8 \pm 0.9)$ (Fig. 4). Anatomical morphologies were consistent with the control group that received vehicle as treatment (Fig. 5). The morphometric analysis (Table 4) revealed significant differences only in the diameter of the heart $(8.8 \pm 0.45 \mathrm{~mm})$ in mice exposed to AE for $24 \mathrm{~h}$ and in the weight of the spleen after $24 \mathrm{~h}(0.10 \pm 0.03 \mathrm{~g})$ or 14 days $(0.14 \pm 0.01 \mathrm{~g})$ of treatment with FF $(p \leq 0.05$, ANOVA). However, the changes observed in these organs did not present a \% ROW lower or higher than $10 \%$ with respect to the control group; thus, these changes can be considered unrelated to pathological causes [41]. Subsequently, histological sections of organs were prepared to search for differences in cellular morphology compared with the control group (Fig. 6a and b). In all cases, control as well as treated animal organs displayed a normal appearance. In spleen, at $10 \mathrm{X}$ magnification, capsules with trabeculae were observed, and the splenic parenchyma consisted of white and red pulp; at 40X magnification, a Malpighian corpuscle was observed, in which the central artery surrounded by the germinal center and lymphocytes were distinguished. At 10X magnification, the kidney exhibited its typical external crust and internal medulla, while at 40X magnification, numerous collecting tubes with a rectilinear path and renal glomeruli surrounded by Bowman's capsule were observed. At 10X magnification, the lungs showed the visceral leaf of the pleura surrounding the pulmonary parenchyma with some bronchi and bronchioles, as well as blood vessels of different caliber and empty spaces corresponding to alveolar sacs, while at 40X, the bronchial wall and muscular layer were observed. At 10X, the heart showed numerous striated muscle fibers surrounded by connective tissue with abundant blood vessels, while at 40X, cardiac muscle fibers with a central nucleus and intercalary discs were observed. In the liver, the portal triad composed of a portal vein, the hepatic artery and a biliary canal, were clearly observed at both magnifications. Based on these results, histological lesions were ruled out during the RHTR treatments. Finally, a hematological analysis revealed slight leukopenia in mice treated with the $A E$ at 14 days after administration and with the FF during the different evaluation times, as well as mild erythropenia compared with the control group ( $p \leq 0.05$, ANOVA) or reference values (Table 5), while the biochemical analysis demonstrated an elevation in the AST for AE and ALT for $\mathrm{FF}$ at $24 \mathrm{~h}$ after administration $(p \leq 0.05$, ANOVA).

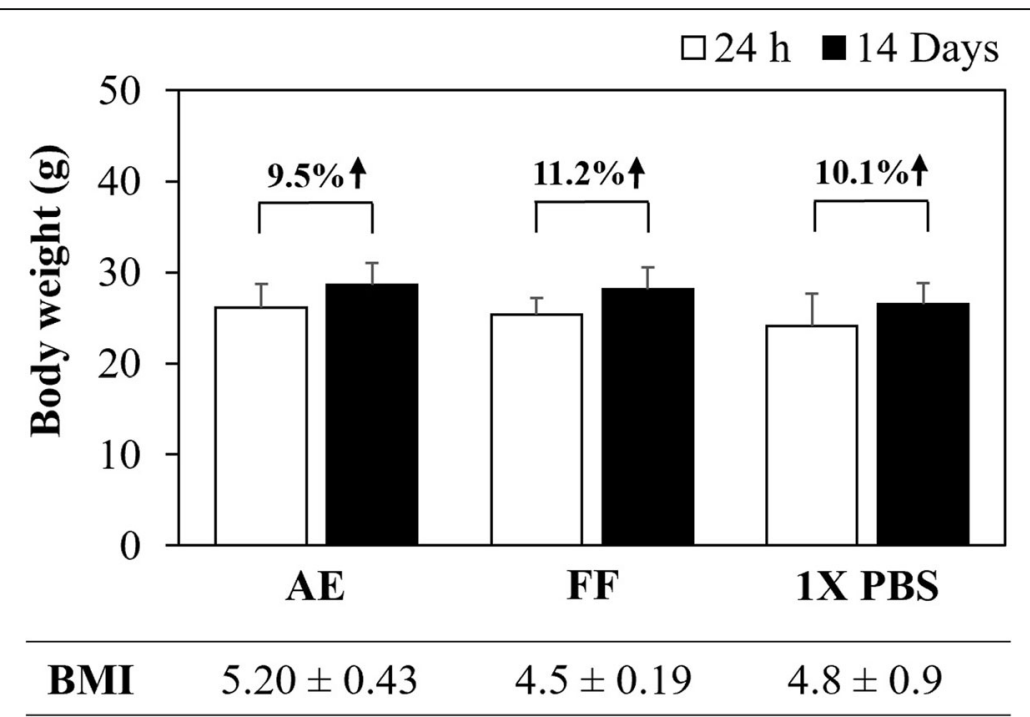

Fig. 4 Body weight evaluation of BALB/C mice treated with RHTR. Effect of AE and FF from RHTR at $200 \mathrm{mg} / \mathrm{kg}$ on the body weight of mice at 24 $\mathrm{h}$ and 14 days posttreatment, where percentages indicate weight gain. The table shows the body mass index (BMI). The results show the mean \pm S.D. of two biological replicates $(n=5) ;{ }^{*}, p<0.05$ vs the control group without treatment (1X PBS) 


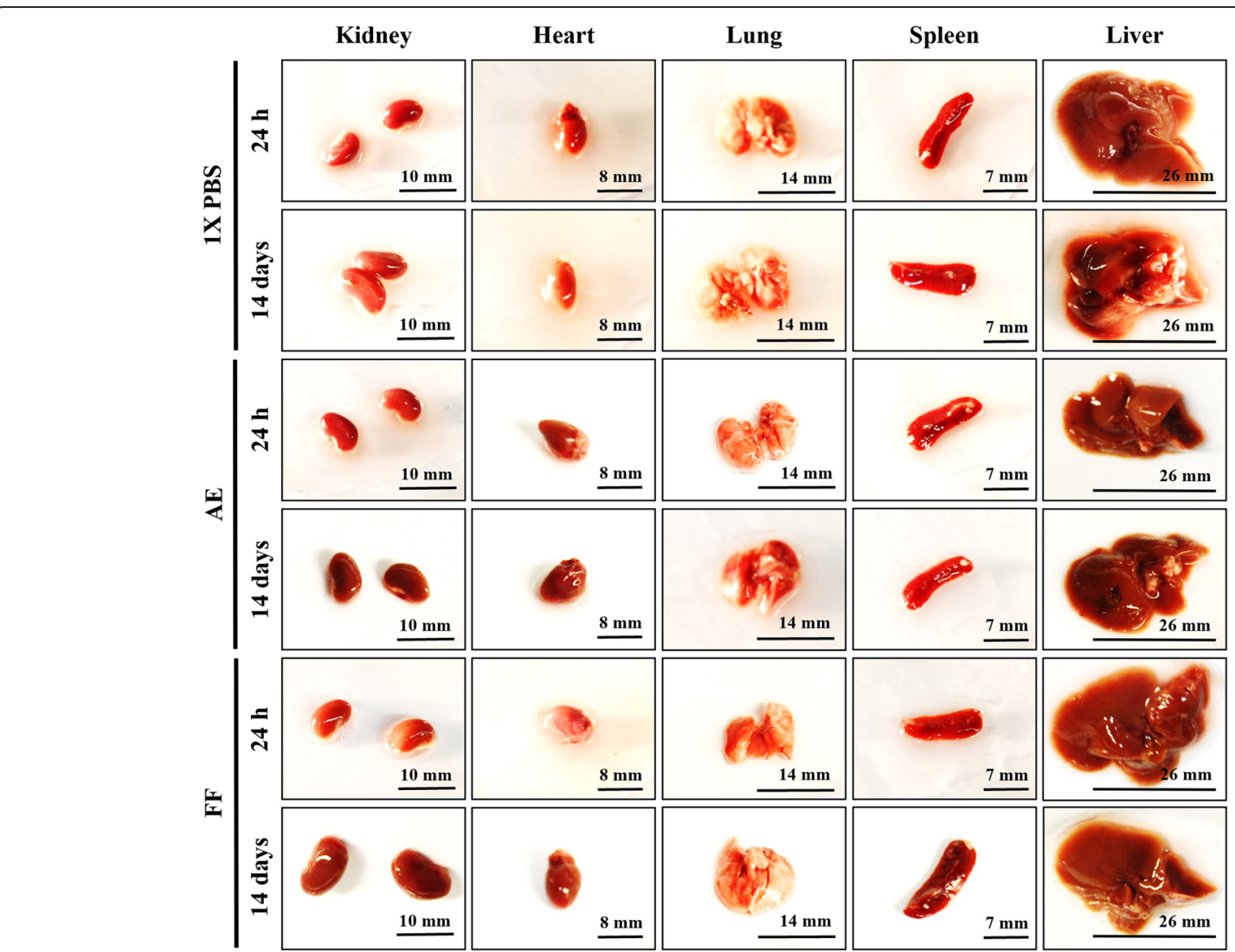

Fig. 5 Morphological analyses of organs extracted from necropsy of BALB/C mice treated with RHTR. Anatomical observations of the main organs extracted in the laparotomy were performed. The results are representative of two biological replicates $(n=5)$

Table 4 Morphometric analysis of organs in BALB/C mice treated with RHTR

\begin{tabular}{llllllll}
\hline Time & Treatment & Measurement & Kidney & Heart & Lung & Spleen & Liver \\
\hline $24 \mathrm{~h}$ & AE & W & $0.36 \pm 0.04(1.4 \%)$ & $0.13 \pm 0.02(0.5 \%)$ & $0.22 \pm 0.02(0.8 \%)$ & $0.11 \pm 0.01(0.4 \%)$ & $1.44 \pm 0.2(5.5 \%)$ \\
& & D & $9.23 \pm 0.5$ & $8.8 \pm 0.45 *$ & $11.04 \pm 1.4$ & $14.5 \pm 1.16$ & $29.6 \pm 0.96$ \\
& FF & W & $0.37 \pm 0.04(1.5 \%)$ & $0.12 \pm 0.01(0.5 \%)$ & $0.22 \pm 0.05(0.9 \%)$ & $0.10 \pm 0.03 *(0.4 \%)$ & $1.36 \pm 0.3(5.4 \%)$ \\
& & D & $10.17 \pm 0.8$ & $8.42 \pm 0.64$ & $11.6 \pm 0.42$ & $15.1 \pm 1.8$ & $26.1 \pm 2.96$ \\
& IX PBS & W & $0.35 \pm 0.06(1.4 \%)$ & $0.12 \pm 0.02(0.5 \%)$ & $0.23 \pm 0.03(0.9 \%)$ & $0.13 \pm 0.02(0.5 \%)$ & $1.3 \pm 0.21(5.4 \%)$ \\
& & D & $10.06 \pm 0.5$ & $8.19 \pm 1.2$ & $11.94 \pm 1.1$ & $14.1 \pm 2.12$ & $27.9 \pm 1.2$ \\
14 days & AE & W & $0.37 \pm 0.01(1.3 \%)$ & $0.16 \pm 0.02(0.5 \%)$ & $0.26 \pm 0.02(0.9 \%)$ & $0.11 \pm 0.01(0.4 \%)$ & $1.29 \pm 0.09(4.5 \%)$ \\
& & D & $10.3 \pm 0.55$ & $9.5 \pm 1.7$ & $13.74 \pm 0.9$ & $17.4 \pm 1.15$ & $28.6 \pm 4.83$ \\
& FF & W & $0.22 \pm 0.14(0.8 \%)$ & $0.17 \pm 0.02(0.6 \%)$ & $0.28 \pm 0.05(0.9 \%)$ & $0.14 \pm 0.01 *(0.5 \%)$ & $1.48 \pm 0.15(5.3 \%)$ \\
& & D & $10.34 \pm 0.4$ & $9.35 \pm 0.14$ & $13.93 \pm 1.7$ & $17.01 \pm 0.6$ & $30.5 \pm 0.86$ \\
& IX PBS & W & $0.35 \pm 0.05(1.3 \%)$ & $0.16 \pm 0.03(0.6 \%)$ & $0.21 \pm 0.01(0.8 \%)$ & $0.12 \pm 0.01(0.5 \%)$ & $1.35 \pm 0.12(5.1 \%)$ \\
& & D & $10.8 \pm 0.6$ & $10.03 \pm 0.8$ & $14.6 \pm 2.95$ & $15.2 \pm 1.4$ & $31.8 \pm 3.3$ \\
\hline
\end{tabular}

The results show the mean \pm S.D. of two biological replicates $(n=5)$

Measurement of W: weight ( $\mathrm{g}$ ), D: larger diameter $(\mathrm{mm})$ and (\% ROW): relative organ weight, for each organ

$*, p<0.05$ vs control values without treatment (1X PBS)

$A E$ aqueous extract, $F F$ flavonoid fraction 

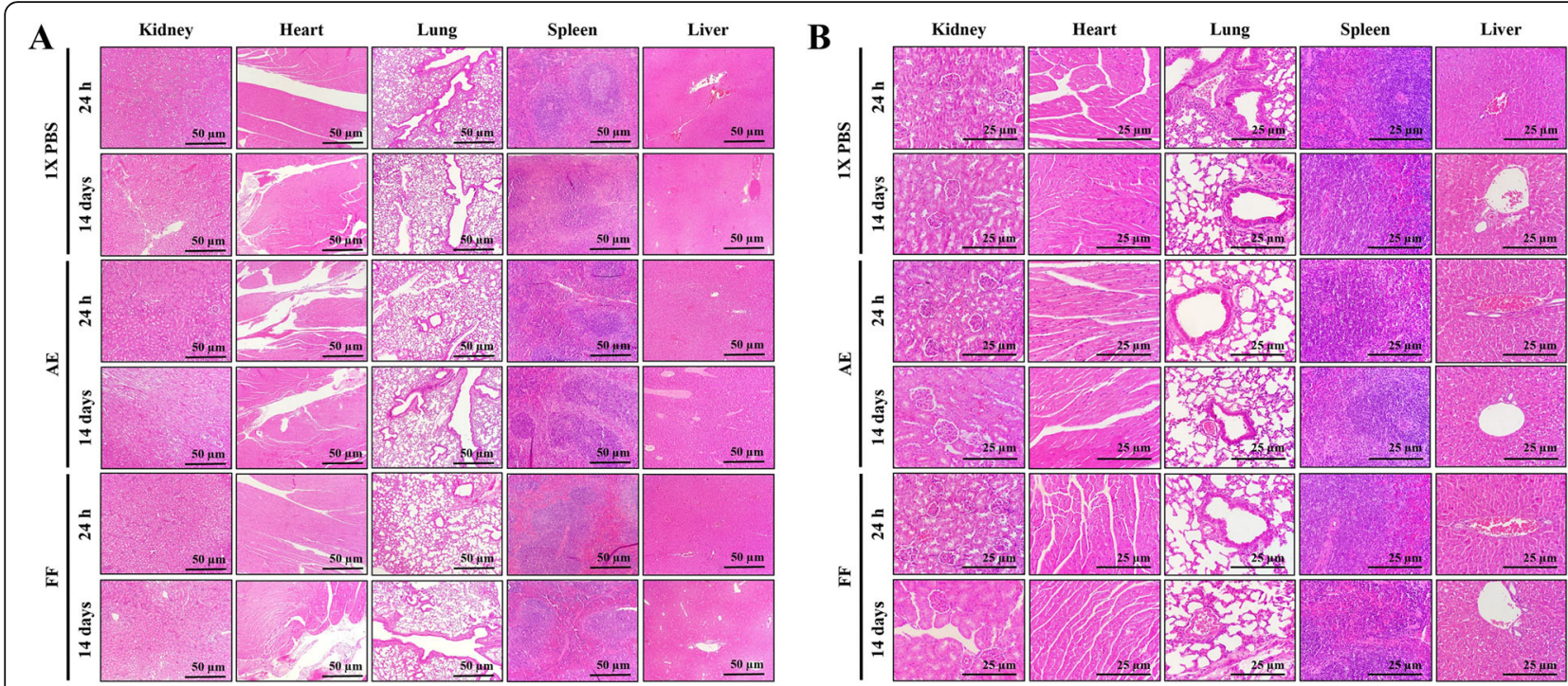

Fig. 6 Histological analyses of organs obtained from mid-laparotomy of BALB/C mice treated with RHTR. Representative sections of mouse kidney, heart, lung, spleen and liver shown at 10X (a) and 40X (b) magnifications. The results are representative of two biological replicates $(n=5)$

Hence, other parameters such as total proteins and albumin were considered to rule out the deterioration of hepatic function, which were within the normal reference range for mice. Triglycerides were slightly elevated after 14 days of starting treatment with $\mathrm{AE}$ with respect to the control group, but the above mentioned values were also maintained within the normal reference range for mice (Table 5). These results suggest a faint suppression of hematopoiesis in the bone marrow during the administration of the AE and FF from RHTR due to the highly replicative phenotype of the blood cells [46]; however, the biochemical parameters did not reveal hepatic dysfunction or renal impairment, and therefore, the use of RHTR may be considered as an alternative cancer treatment.

\section{Phytochemical characterization of AE and FF from RHTR}

In RHTR, 173 compounds among 272 features present in AE were putatively identified by comparison with databases for plants (Additional file 3: Table S1). The UV profile at $280 \mathrm{~nm}$ and TIC of AE-RHTR showed that the major classes of compounds were flavonoids (29\%), followed by fatty acids (22\%), phenolic acids (11\%) and glycosylated compounds (10\%) (Fig. 7a). The most abundant compounds in AE-RHTR were galactinol (2), 1-O-galloyl- $\beta$-D-glucose (8), quinic acid (21), methyl gallate (43), epigallocatechin 3-cinnamate (52), quercetin 3 -(2"'-galloylglucosyl)-( $(\rightarrow 2)$-alpha-L-arabinofuranoside (84), 1,2,3,4,6-pentakis-O-galloyl- $\beta$-D-glucose $(\beta$-PGG, 86), 4-O-digalloyl-1,2,3,6-tetra- $O-\beta$-D-galloylglucose (94), myricetin 3-(4"-galloylrhamnoside) (112), fisetin (130) and margaric acid (134) (Additional file 3: Table S1, Fig. 7a), which were identified by the fragmentation patterns of each compound and by matching their retention times with analytical standards (Additional file 2: Figure S2); all of these compounds present diverse activities in plants as primary or secondary metabolites. However, comparing the metabolite profiles of $\mathrm{AE}$ and FF showed that 43 (RT, 6.44), 52 (RT, 7.05), 84, 86 (RT, 8.52), 94 (RT, 9.13), 112 (RT, 9.97), 130 (RT, $11.92)$ and 134 (RT, 12.54) maintained a high relative abundance in both samples (Additional file 3: Table S1, Fig. 7b). These compounds have been reported to possess cytotoxic activity in cancer cells $[13,44,47]$ and may be related to the medicinal properties of RHTR observed in this study (Additional file 3: Table S1). However, complementary studies are required to demonstrate whether there is a major compound in FF or a responsible synergistic mechanism. Additionally, urushiol, a toxic compound present in other Rhus sp., was not detected in AE and FF. Studies in RHTR have reported that gallic acid and ethyl gallate are among the main bioactive compounds in plants [10]. In our study, gallic acid (80) was found in $\mathrm{AE}$ and $\mathrm{FF}$, whereas ethyl gallate was not present. However, 43 (RT, 6.44) was detected as mentioned above (Additional file 3: Table S1). The presence of gallic acid and methyl gallate in the extracts was derived from catabolic reactions of $\beta$-PGG, which is used by RHTR to elaborate new secondary metabolites against different stressors $[48,49]$. Recent studies have shown that medicinal plants that are thermally processed by decoction or infusion, compared with other forms of preparation, have increased biological activity caused by chemical changes during heat treatment [50].

\section{Discussion}

Plants can produce secondary metabolites, such as alkaloids, terpenoids and polyphenols, among other compounds, which can play an important role in the prevention and treatment of various diseases [51]. In 
Table 5 Effect of RHTR on biochemical and hematological parameters of $B A L B / C$ mice in the acute toxicity study

\begin{tabular}{|c|c|c|c|c|c|c|c|}
\hline \multirow{2}{*}{$\begin{array}{l}\text { Time } \\
\text { Treatment }\end{array}$} & \multicolumn{3}{|l|}{$24 \mathrm{~h}}$. & \multicolumn{3}{|l|}{14 days } & \multirow{2}{*}{$\begin{array}{l}\text { Reference range } \\
\text { (Midrange) }\end{array}$} \\
\hline & $\mathrm{AE}$ & $\mathrm{FF}$ & $1 \times$ PBS & $\mathrm{AE}$ & $\mathrm{FF}$ & $1 \mathrm{X}$ PBS & \\
\hline \multicolumn{8}{|l|}{ BIOCHEMICAL PARAMETERS } \\
\hline Glucose (mg/dL) & $118.7 \pm 13.8$ & $113.7 \pm 17.5$ & $138.7 \pm 17.9$ & $130.2 \pm 6.9$ & $127.7 \pm 15.4$ & $141.5 \pm 10.4$ & 63-176 (89) \\
\hline Triglycerides (mg/dL) & $70.13 \pm 11.3$ & $74.6 \pm 7.4$ & $81.4 \pm 8.6$ & $121.8 \pm 17.2$ & $112.75 \pm 19.8$ & $98.5 \pm 7.3$ & $55-115(85)$ \\
\hline Cholesterol (mg/dL) & $76.3 \pm 8.5$ & $77.5 \pm 14.4$ & $75 \pm 8.2$ & $61 \pm 12.7$ & $55 \pm 5.8$ & $65 \pm 2.8$ & $26-82(64)$ \\
\hline Protein (g/dL) & $5.4 \pm 0.5$ & $5.5 \pm 0.6$ & $5.4 \pm 0.25$ & $5.7 \pm 0.63$ & $5.2 \pm 0.5$ & $5.8 \pm 0.82$ & $4-8.6(6.2)$ \\
\hline AST (TGO) (U/L) & $205 \pm 45.3 *$ & $152.5 \pm 8.7$ & $127.5 \pm 19.4$ & $132 \pm 19.7$ & $165 \pm 45.5$ & $161.8 \pm 47.5$ & $55-251(139)$ \\
\hline ALT (TGP) (U/L) & $55.9 \pm 8.8$ & $78.7 \pm 0.3 *$ & $52.9 \pm 6.2$ & $64.4 \pm 1.4$ & $74.7 \pm 16.1$ & $70.7 \pm 5.8$ & $17-77(47)$ \\
\hline $\mathrm{LDH}(\mathrm{U} / \mathrm{L})$ & $1234 \pm 221$ & $954 \pm 281$ & $1330 \pm 274$ & $1122 \pm 201$ & $980 \pm 286$ & $997.3 \pm 70.3$ & $149-215(182)$ \\
\hline Creatinine (mg/dL) & $0.62 \pm 0.2$ & $0.5 \pm 0.01$ & $0.5 \pm 0.01$ & $0.5 \pm 0.01$ & $0.5 \pm 0.01$ & $0.46 \pm 0.09$ & $0.2-0.9(0.5)$ \\
\hline Urea (mg/dL) & $60 \pm 5.8$ & $56.2 \pm 4.8$ & $53.7 \pm 6.3$ & $65 \pm 4.1$ & $57.5 \pm 6.5$ & $56.7 \pm 7.2$ & $46.9-73(60.1)$ \\
\hline \multicolumn{8}{|c|}{ HEMATOLOGICAL PARAMETERS } \\
\hline Hemoglobin (g/dL) & $15.16 \pm 1.09$ & $13.5 \pm 0.36$ & $14.76 \pm 0.90$ & $16 \pm 1.05$ & $13.23 \pm 1.8$ & $14.13 \pm 0.20$ & $10-17(13.1)$ \\
\hline Hematocrit (\%) & $47.2 \pm 4.07$ & $39.33 \pm 3.40$ & $43.93 \pm 2.83$ & $49.5 \pm 3.99$ & $38.8 \pm 5.63$ & $43.7 \pm 0.55$ & $39-49(40.4)$ \\
\hline $\begin{array}{l}\text { Erythrocytes }\left(\times 10^{6} /\right. \\
\left.\mathrm{mm}^{3}\right)\end{array}$ & $9.69 \pm 1.16$ & $7.34 \pm 0.95$ & $9.27 \pm 0.97$ & $9.92 \pm 0.85$ & $7.91 \pm 1.13$ & $8.84 \pm 0.43$ & 8.3 \\
\hline $\mathrm{MCHC}(\%)$ & $32.06 \pm 0.66$ & $36.36 \pm 4.56$ & $33.63 \pm 1.04$ & $32.3 \pm 0.52$ & $36.26 \pm 2.57$ & $32.3 \pm 0.72$ & 32.3 \\
\hline $\mathrm{MCH}(\mathrm{pg})$ & $15.66 \pm 0.8$ & $14.63 \pm 3.68$ & $15.96 \pm 0.96$ & $16.1 \pm 0.34$ & $14.3 \pm 2.4$ & $15.96 \pm 0.86$ & 15.9 \\
\hline $\mathrm{MCV}(\mu \mathrm{L})$ & $48.9 \pm 1.6$ & $47.26 \pm 11.49$ & $47.5 \pm 1.83$ & $49.9 \pm 0.3$ & $48.9 \pm 1.95$ & $49.5 \pm 1.83$ & 49.1 \\
\hline $\begin{array}{l}\text { Leukocytes ( } \times 100 / \\
\mathrm{mm}^{3} \text { ) }\end{array}$ & $5000 \pm 953.9$ & $4233.3 \pm 1404.7$ & $\begin{array}{l}5666.66 \pm \\
808.29\end{array}$ & $\begin{array}{l}4466.66 \pm \\
929.15\end{array}$ & $4666.6 \pm 1242.3$ & $\begin{array}{l}5033.33 \pm \\
1227.8\end{array}$ & $5-12(6.33)$ \\
\hline RDW-CV & $15 \pm 1.17$ & $18.7 \pm 1.56$ & $17.96 \pm 1.11$ & $13.73 \pm 0.57 *$ & $16.33 \pm 0.97$ & $16.16 \pm 1.20$ & \\
\hline RDW-SD & $24.26 \pm 3.18 *$ & $32.63 \pm 18.9$ & $33.2 \pm 5.32$ & $22.8 \pm 0.51^{*}$ & $26.13 \pm 1.5$ & $25.73 \pm 1.38$ & \\
\hline Platelets $(/ \mu \mathrm{L})$ & $\begin{array}{l}437,333 \pm \\
94,214\end{array}$ & $\begin{array}{l}558,666.6 \pm \\
230,048.5\end{array}$ & $\begin{array}{l}627,000 \pm \\
95,859.2\end{array}$ & $\begin{array}{l}368,000 \pm \\
46,130\end{array}$ & $\begin{array}{l}425,333.3 \pm \\
325,423\end{array}$ & $\begin{array}{l}572,666 \pm \\
158,190\end{array}$ & $116 \times 10^{3}$ \\
\hline MPV (fL) & $7.6 \pm 0.2$ & $7.5 \pm 2.4$ & $8.16 \pm 0.87$ & $7.56 \pm 0.15$ & $9.43 \pm 0.49 *$ & $7.6 \pm 0.3$ & \\
\hline PDW (\%) & $14 \pm 0.1$ & $14.6 \pm 4.5$ & $14.96 \pm 2.32$ & $14.06 \pm 0.15$ & $13.03 \pm 2.8$ & $14 \pm 0.26$ & \\
\hline РСТ (\%) & $0.33 \pm 0.07 *$ & $0.27 \pm 0.05 *$ & $0.51 \pm 0.12$ & $0.277 \pm 0.03 *$ & $0.585 \pm 0.12$ & $0.432 \pm 0.10$ & \\
\hline Lymphocytes (\%) & $67.33 \pm 10.06 *$ & $74 \pm 7.21$ & $82 \pm 2$ & $65 \pm 13.4$ & $63.3 \pm 4.16$ & $68 \pm 20.7$ & $35-90$ \\
\hline Monocytes (\%) & $1.33 \pm 1.15$ & 0 & $0.33 \pm 0.57$ & $0.33 \pm 0.57$ & 0 & 0 & $0-3$ \\
\hline Eosinophils (\%) & 2 & 0 & 0 & 0 & 0 & 0 & $0-7$ \\
\hline Basophils (\%) & 0 & 0 & 0 & 0 & 0 & 0 & $0-1$ \\
\hline $\begin{array}{l}\text { Segmented } \\
\text { neutrophils (\%) }\end{array}$ & $38 \pm 9.16 *$ & $25.3 \pm 7.5$ & $17.66 \pm 2.08$ & $34.66 \pm 13.61$ & $16.66 \pm 4.16$ & $24.66 \pm 27.30$ & $10-40$ \\
\hline Neutrophils band (\%) & 0 & 0 & 0 & 0 & 0 & 0 & 0 \\
\hline Immature shape (\%) & 0 & 0 & 0 & 0 & 0 & 0 & 0 \\
\hline
\end{tabular}

The results show the mean \pm S.D. of two biological replicates $(n=5)$

The numbers in bold indicate differences with respect to reference values for the mouse

*, $p<0.05$ vs the $1 \mathrm{X}$ PBS control group (without treatment)

References range, minimum and maximum normal value for the analyte of interest in $B A L B / C$ mice and the respective midrange

$A E$ aqueous extract, $F F$ flavonoid fraction

AST (TGO) aspartate aminotransferase, $A L T$ (TGO) alanine aminotransferase, $L D H$ lactate dehydrogenase, $M C H C$ mean corpuscular hemoglobin concentration, $M C H$ mean corpuscular hemoglobin, $M C V$ mean corpuscular volume, $R D W$ - $C V$ red blood cell distribution width as coefficient of variation, $R D W$-SD red blood cell distribution width as standard deviation, MPV mean platelet volume in femtoliters, PDW platelet distribution width, PCT platelecrit

vitro studies with $\mathrm{AE}$ and FF from RHTR on different cell lines have shown that low concentrations of both samples have a selective inhibitory effect on CACO-2 cell proliferation through induction of a quiescent/cytostatic state and later activation of an apoptotic process, compared with BEAS-2B and CHO-K1 normal cells. Some studies have demonstrated that malignant cell populations may experience a state of persistent cytostasis due to intrinsic and exogenous cellular factors, such as DNA damage, alteration of cyclin-dependent kinases 

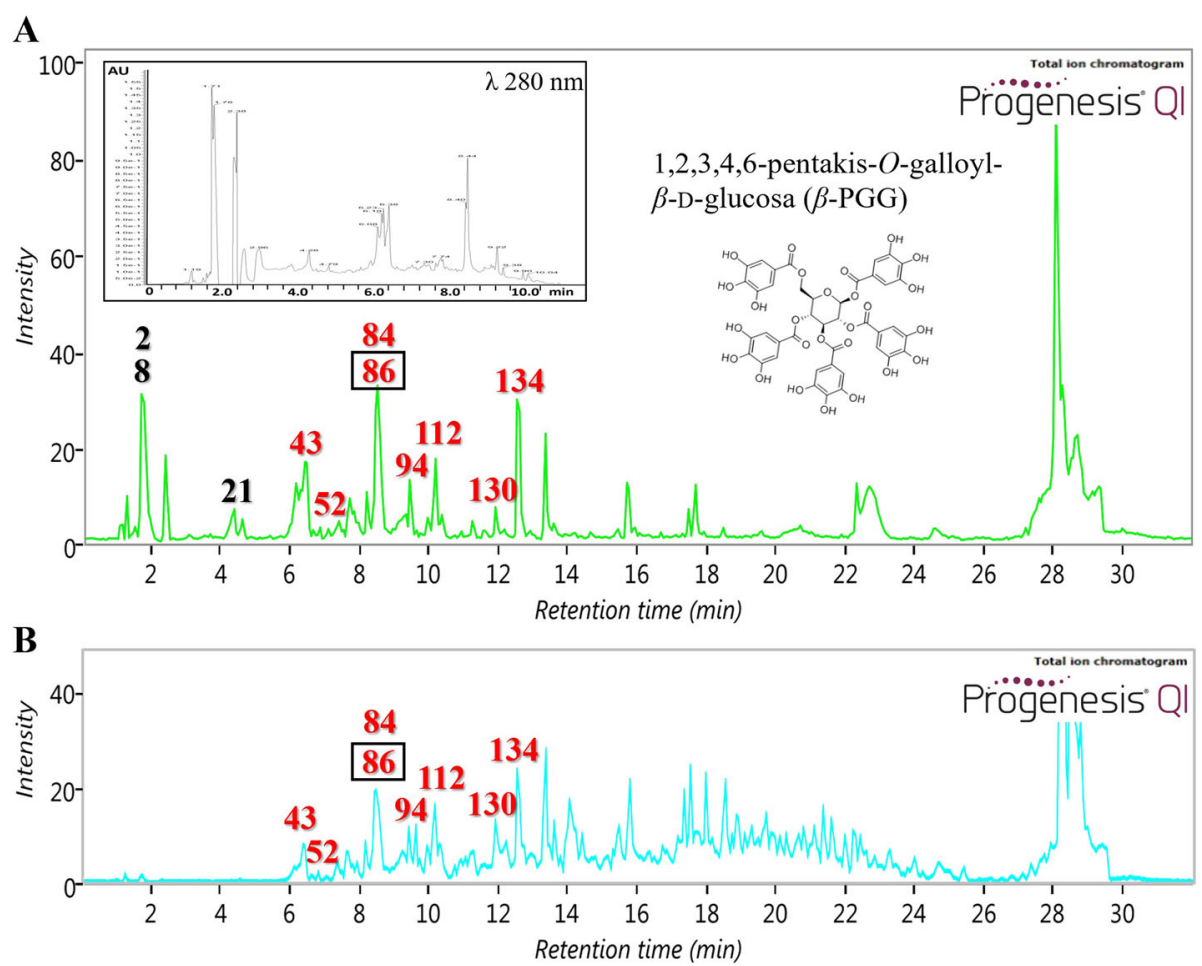

Fig. 7 Chromatographic profile of RHTR by UPLC-MSE. TIC on ESI' of AE (a) and FF (b) from RHTR showing the metabolic profiles of both samples with 173 preidentifications. The main compounds are indicated by the number of the corresponding order of appearance in Additional file 3: Table S1. The most abundant compounds in AE and FF are marked in red. The compound with higher relative abundance was identified, and a fingerprint of AE-RHTR by UPLC-PAD analysis at $\lambda 280 \mathrm{~nm}$ is indicated in the corresponding inset. The results are representative of three biological replicates $(n=3$, in triplicate)

and components of the PI3K signaling pathway or production of oxidative environments, among others [52]. These conditions can be induced by polyphenolic compounds present in plants such as RHTR. Therefore, the metabolic profiles of AE and FF from RHTR were analyzed to preidentify the major compounds. The analysis revealed a high content of polyphenols and flavonoids with antioxidant activity in AE-RHTR, which included methyl gallate, epigallocatechin 3-cinnamate, quercetin 3-(2"'-galloylglucosyl)-(1 $\rightarrow 2)$-alpha-L-arabinofuranoside, $\beta$-PGG, 4-O-digalloyl-1, 2, 3, 6-tetra- $O-\beta$-D-galloylglucose, myricetin 3-(4"-galloylrhamnoside), and fisetin. The concentrations of these compounds were increased in the FF fraction, and other research groups have reported that some of these compounds are important active principles against cancer by activating different molecular mechanisms involved in the state of quiescence and cell death [13, 44, 47]. Thus, we considered that the antineoplastic activity observed in RHTR might be related to the combination of these compounds in the AE. However, complementary studies are required to demonstrate if there is a major compound in FF or a synergistic mechanism responsible for the medicinal properties of RHTR. Moreover, urushiol, a toxic compound present in other Rhus sp., was not detected in RHTR. The Rhus genus has been shown to have a high concentration of phenolic compounds, such as gallic acid (among other gallates), and flavonoids, such as fustin, myricetin, quercetin, butein and sulfuretin, with antioxidant, anti-inflammatory, antibacterial, antiparasitic and anticancer activities reported for $R$. verniciflua, $R$. succedanea and $R$. coriaria, respectively [13]. The most studied mechanism of polyphenols is their anti/pro-oxidant effect. Studies performed with green tea polyphenols (Camellia sinensis) $[43,53]$ have demonstrated that these compounds undergo auto-oxidative reactions resulting in the production of ROS, which play an important role in cells $[44,54]$. Several authors have shown that ROS act as second messengers and modulate the activity of various processes related to the cytoskeleton, the cell cycle and cell death in cancer and normal cells, such as inhibition of $\beta$-transforming growth factor $(\mathrm{TGF}-\beta)$ and epidermal growth factor (EGF), or phosphorylation of histone 2A.X ( $\gamma$ H2A.X) (a marker of oxidative DNA damage), among others [55, 56]. Additionally, polyphenols have a selective effect on cancer cells because they exhibit a reduced regulation of the cellular machinery and, therefore, are more sensitive to 
the induction of quiescence and apoptosis, while normal cells can activate endogenous antioxidant mechanisms (e.g., glutathione $S$-transferase, $\gamma$-glutamyltransferase, and superoxide dismutase) to prevent cell death by DNA damage or lipid peroxidation [57, 58]. Therefore, this background could explain why the flavonoids in RHTR selectively induced cell cycle arrest in $\mathrm{G}_{1}$ and cell death via apoptosis at a lower concentration in CACO-2 but not in $\mathrm{CHO}-\mathrm{K} 1$ and BEAS-2B cells. Moreover, studies have indicated that high doses of polyphenols have potential toxicity, possibly due to differences in the sensitivity, metabolism and bioavailability of polyphenols among individuals [44]. In humans, elevations of serum transaminase and bilirubin levels, abdominal pain, jaundice, portal/periportal inflammation and necrosis have been observed, all of which are symptoms related to hepatotoxicity [53, 59]. Therefore, toxicological assays with RHTR in the animal model were performed to determine possible adverse effects during its consumption. Regarding the toxicological study, the administration to rodents of $200 \mathrm{mg} / \mathrm{kg}$ of AE and FF from RHTR did not reveal behavioral changes or signs of toxicity. When performing necropsy for morphometric and histopathological analysis, no significant anatomical changes or histological lesions were found in the organs recovered from the different treatment groups with respect to the control group. However, hematological parameters revealed slight leukopenia in mice treated with $\mathrm{AE}$ and $\mathrm{FF}$ at 14 days posttreatment. Additionally, FF caused mild erythropenia compared with the control group and reference values. These results suggested a faint suppression of hematopoiesis in the bone marrow during administration of the $\mathrm{AE}$ and $\mathrm{FF}$ from RHTR, possibly due to the highly replicative phenotype of blood cells, which are more sensitive to the action of different cytotoxic compounds, as is often the case during the administration of chemotherapies in the treatment of cancer [46]. Our results regarding animal toxicity are similar to those found for $R$. verniciflua, for which the toxicity of fermented Rhus verniciflua stem bark extract (FRVSB, urushiol-free) was evaluated in Sprague-Dawley rats at a simple oral dose and at repeated doses of $5000 \mathrm{mg} / \mathrm{kg}$ body weight for 90 days, without observing the death of any rodent or adverse effects on clinical signs, body weight or food consumption [60]. When performing necropsy, the organs did not present anatomical or histological alterations during both tests, and analysis of biochemical and hematological parameters revealed no differences compared with the reference range for rats [60]. These results together with those discussed previously strongly suggest that, minimally, the $\mathrm{AE}$ and/or FF derived from RHTR could be administered without risk of affecting health and, most likely, without causing adverse effects as severe as those observed during the administration of conventional chemotherapy.

\section{Conclusions}

The results obtained in this study demonstrated a selective antiproliferative activity of AE and FF from RHTR against CACO-2 colon cancer cells. This activity was found to be related to ROS generation that induced a quiescent state and later apoptotic process. Among the most abundant compounds were methyl gallate, epigallocatechin 3cinnamate, quercetin 3-(2"'-galloylglucosyl)-( $\rightarrow 2)$ alpha-L-arabinofuranoside, $\beta$-PGG, 4-O-digalloyl-1,2,3,6tetra-O- $\beta$-D-galloylglucose, myricetin 3-(4" -galloylrhamnoside), and fisetin. It has been demonstrated that these compounds can produce ROS and activate different molecular mechanisms involved in the state of quiescence and cell death; thus, the antineoplastic activity observed in RHTR might be related with these compounds. However, complementary studies are required to demonstrate this correlation. Moreover, these compounds could be considered as future prospects for more detailed studies. Furthermore, the results from the toxicological assay did not reveal significant anatomical changes or histological lesions in the organs recovered from the treatments with $\mathrm{AE}$ and FF, thus suggesting that RHTR might be nontoxic upon acute exposure during i.p. administration in mice. However, hematologic studies suggested that the RHTR decoction might have suppressive effects on hematopoietic processes if used at high concentrations for prolonged periods. Thus, it is suggested that this agent be used with caution. Finally, the high concentration of polyphenols and antioxidants in AE may have beneficial effects as chemoprotective agents against different degenerative diseases associated with oxidative stress. However, further studies are required to confirm this statement.

\section{Additional files}

Additional file 1: Figure S1. Timeline scheme of the acute toxicity studies described in the experimental procedures. (PPTX $1372 \mathrm{~kb}$ )

Additional file 2: Figure S2. MS/MS analysis of the most abundant compounds in RHTR. (PPTX $1780 \mathrm{~kb}$ )

Additional file 3: Table S1. Phytochemical compounds putatively identified in RHTR by UPLC-MSE. (XLSX $37 \mathrm{~kb})$

\footnotetext{
Abbreviations

$\mathrm{AC}_{50}$ : Half antioxidant concentration; ACs: Active compounds; AE: Aqueous extract; AEl: Antioxidant efficient index; AraCyc: Metabolic pathway databases for Arabidopsis thaliana; BMI: Body mass index; BWC: Body weight change; CM- ${ }_{2}$ DCFDA: (5-(and-6)-chloromethyl-2',7'-dichlorodihydrofluorescein diacetate; DPPH: 2,2 diphenyl-1-picrylhydrazyl; EGF: Epidermal growth factor; ESI: Electrospray ionization source; EtOH: Ethanol; FBS: Fetal bovine serum; FF: Flavonoid fraction; HMDB: Human metabolome database; i.p: Intraperitoneal; $I C_{50}$ : Half-maximal inhibitory concentration; KEGG: Kyoto encyclopedia of genes and genomes; LD 50 : Median lethal dose; MeOH: Methanol; MI: Mitotic index; MS: Mass spectrometry; MTT: 3-(4,5-
} 
dimethylthiazol-2-yl)-2,5-diphenyltetrazolium bromide; PAD: Photodiode array detector; PlantCyc: Plant metabolic pathway databases; RHTR: Rhus trilobata: ROS: Reactive oxygen species; ROW: relative organ weight; SI: Selective index; TGF- $\beta$ : Transforming growth factor beta; TIC: Total ion chromatogram; Trolox: 6-hydroxy-2,5,7,8-tetramethylchroman-2-carboxylic acid; UPLC: Ultraperformance liquid chromatography; UV: Ultraviolet; $\beta$-PGG: 1,2,3,4,6-pentakisO-galloyl- $\beta$-D-glucose

\section{Acknowledgments}

The authors are grateful to Sonia Rodríguez de la Rocha, Toutcha Lebgue Keleng and Laura de León Pesqueira for their involvement in the identification of samples collected from Rhus trilobata; Esperanza Ayala Gil, José Vinicio Torres Muñoz and Leticia Burciaga García for participating in the phytochemical characterization of the plant; Julieta Rubio Lightbourn and José Eduardo Pérez Salazar for the donation of cell lines; Victor Hugo Rosales García for his collaboration with the flow cytometry analysis; Verónica Ivonne Hernández Ramírez for her advice in the confocal microscopy studies; Carmen Selene Ramírez Vera (Merasoma Laboratory) for her help with the veterinary blood sample analyses; and Daniel Morales Mora for the technical support.

\section{Authors' contributions}

LVR carried out most of the experiments and wrote the manuscript; BSR (codirector of the project) conceived the project idea and participated in the financing and drafting/review of the manuscript; ISRR performed the toxicity assays; JJOO, DChF and ESM participated in the phytochemical characterization of Rhus trilobata and reviewed the manuscript; JCOT collaborated in the cell culture and in vitro assays; ERM provided assistance and advice with the histopathological assays; PTR (director of the project) was responsible for the financing (reagents/materials/analysis tools) and drafting and reviewing of the manuscript. All authors read and approved the final manuscript.

\section{Funding}

This research was partially supported by FOMIX-Chihuahua-CONACyT $(\mathrm{CHIH}-$ 2010-C01-143572) and a basic science research project CONACyT (CB-201301-221136) to BSR and PTR, respectively. LVR was a recipient of a Ph.D. scholarship from CONACyT (Reg. 369164). The funds have been used in areas such as experimentation, analysis and interpretation of data.

\section{Availability of data and materials}

All data generated or analyzed during this study are included in this published article (as well as supplementary information files). Raw data are available from the corresponding author on reasonable request.

\section{Ethics approval and consent to participate}

This study was carried out in accordance with Official Mexican Regulations (NOM-062-ZOO-1999), and the protocol was approved by the Institutional Animal Care and Use Committee (Authorization No. 0010/11) from the Faculty of Chemical Sciences, UACH.

\section{Consent for publication}

Not applicable.

\section{Competing interests}

The authors have no other relevant affiliations or financial involvement with any organization or entity with a financial interest in or financial conflict with the subject matter or materials discussed in the manuscript apart from those disclosed.

\section{Author details}

${ }^{1}$ Departamento de Infectómica y Patogénesis Molecular, CINVESTAV-IPN, Ave. Instituto Politécnico Nacional No. 2508, Col. San Pedro Zacatenco, C.P. 07360 Ciudad de México, Mexico. ${ }^{2}$ Facultad de Ciencias Químicas, Universidad Autónoma de Chihuahua, Circuito No. 1, Nuevo Campus Universitario, C.P. 31125 Chihuahua, Chih., Mexico. ${ }^{3}$ Laboratorio de Metabolómica y Espectrometría de Masas, Unidad de Genómica Avanzada, CINVESTAV-IPN, Libramiento Norte Carretera Irapuato-León Km. 9.6, C.P. 36824 Irapuato, Gto., Mexico. ${ }^{4}$ Departamento de Anatomía Patológica, Hospital CIMA, Av. Hacienda del Valle No. 7120, Fraccionamiento Plaza las Haciendas, C.P. 31217 Chihuahua, Chih., Mexico.
Received: 1 September 2018 Accepted: 17 June 2019 Published online: 01 July 2019

\section{References}

1. Alonso-Castro AJ, Villarreal ML, Salazar-Olivo LA, Gómez-Sánchez M, Domínguez F, García-Carranca A. Mexican medicinal plants used for cancer treatment: pharmacological, phytochemical and ethnobotanical studies. J Ethnopharmacol. 2011;133(3):945-72. https://doi.org/10.1016/j.jep.2010.11. 055.

2. Al-Hrout A, Chaiboonchoe A, Khraiwesh B, Murali C, Baig B, El-Awady R, Tarazi H, Alzahmi A, Nelson DR, Greish YE, Ramadan W, Salehi-Ashtiani K, Amin A. Safranal induces DNA double-strand breakage and ER-stressmediated cell death in hepatocellular carcinoma cells. Sci Rep. 2018;8(1): 16951. https://doi.org/10.1038/s41598-018-34855-0.

3. Ogbourne SM, Parsons PG. The value of nature's natural product library for the discovery of new chemical entities: the discovery of ingenol mebutate. Fitoterapia. 2014;98:36-44. https://doi.org/10.1016/j.fitote.2014.07.002.

4. Kinsley-Scott TR, Norton SA. Useful plants of dermatology. VIl: cinchona and antimalarials. J Am Acad Dermatol. 2003;49(3):499-502. https://doi.org/10. 1067/S0190-9622(03)01281-7.

5. Stranska I, Skalicky M, Novak J, Matyasova E, Hejnak V. Analysis of selected poppy (Papaver somniferum L.) cultivars: pharmaceutically important alkaloids. Ind Crop Prod. 2013;41(1):120-6. https://doi.org/10.1016/j.indcrop. 2012.04.018.

6. Long HJ. Paclitaxel (Taxol): a novel anticancer chemotherapeutic drug. Mayo Clin Proc. 1994;69(4):341-5. https://doi.org/10.1016/S0025-6196(12)62219-8.

7. Schlaepfer L, Mendoza-Espinoza J. Las plantas medicinales en la lucha contra el cáncer, relevancia para México. Rev Mex Cienc Farm. 2010;41(4): 18-27.

8. Lai HY, Lim YY, Kim KH. Blechnum orientale Linn - a fern with potential as antioxidant, anticancer and antibacterial agent. BMC Complementary Altern Med. 2010;10(15):1-8. https://doi.org/10.1186/1472-6882-10-15.

9. Abbott BJ, Leiter J, Hartwell JL, Caldwell ME, Beal JL, Perdue RE, Schepartz SA. Screening data from the cancer chemotherapy national service center screening laboratories. XXXIV. Plant extracts. Cancer Res. 1966;26(9 pt 2): $1131-271$.

10. Pettit GR, Saldana El, Lehto E. Antineoplastic agents 35. Rhus trilobata. Lloydia. 1974;37(3):539-40.

11. Park KY, Jung GO, Lee KT, Choi J, Choi MY, Kim GT, Jung HJ, Park HJ. Antimutagenic activity of flavonoids from the heartwood of Rhus verniciflua. J Ethnopharmacol. 2004;90(1):73-9. https://doi.org/10.1016/j.jep.2003.09.043.

12. Wu PL, Lin SB, Huang CP, RY-Y C. Antioxidative and cytotoxic compounds extracted from the sap of Rhus succedanae. J Nat Prod. 2002;65(11):1719-21. https://doi.org/10.1021/np0201467.

13. Rayne S, Mazza G. Biological activities of extracts from sumac (Rhus sp.): a review. Plant Foods Hum Nutr. 2007;62(4):165-75. https://doi.org/10.1007/ s11130-007-0058-4.

14. McNair JB. Internal poisoning from Rhus. Arch Dermatol Syphilol. 1921;4(1): 62-6. https://doi.org/10.1001/archderm.1921.02350200065006.

15. Park SD, Lee S-W, Chun J-H, Cha S-H. Clinical features of 31 patients with systemic contact dermatitis due to the ingestion of Rhus (lacquer). Br J Dermatol. 2000;142(5):937-42. https://doi.org/10.1046/j.1365-2133.2000. 03474.x.

16. Oh S-H, Haw C-R, Lee M-H. Clinical and immunologic features of systemic contact dermatitis from ingestion of Rhus (Toxicodendron). Contact Dermatitis. 2003;48(5):251-4. https://doi.org/10.1034/j.1600-0536. 2003.00103.x.

17. Rose N. Rhus trilobata: worthy plant seeks worthy name. Arnoldia. 2005; 63(4):23-5.

18. Shaw NL, Debolt AM. Rhus trilobata Nutt. Anacardiaceae. In: John KF, editor. Wildland shrubs of the United States and its territories: Thamnic descriptions. EE.UU.: Department of Agriculture; 2004. 634-636.

19. UNIBIO : Galería Virtual IreKani. http://unibio.unam.mx/irekani/handle/ 123456789/14565?mode=full\&submit_simple=Muestra+el+registro+Dublin+ Core+completo+del+\%C3\%ADtem\&proyecto=Irekani (2008). Accessed 17 Mar 2019

20. CONABIO: Biodiversidad Mexicana, Herbario virtual. http://www.conabio.gob. $\mathrm{m} \times$ /otros/cgi-bin/herbario_imagenes.cgi?familia=Anacardiaceae\&genero= Rhus\&especie=trilobata\&infraesp=\&tipo= (2009). Accessed 17 Mar 2019.

21. WHO: quality control methods for plant materials. http://whqlibdoc.who.int/ publications/1998/9241545100.pdf (1998). Accessed 17 Mar 2019. 
22. Dubois M, Giles K, Hamilton JK, Rebes PA, Smith F. Colorimetric method for determination of sugars and relates substances. Anal Chem. 1956;28(3):3506. https://doi.org/10.1021/ac60111a017.

23. Bradford MM. A rapid and sensitive method for the quantitation of microgram quantities of protein utilizing the principle of protein-dye binding. Anal Biochem. 1976;72(1-2):248-54. https://doi.org/10.1016/00032697(76)90527-3.

24. Rosen $\mathrm{H}$. A modified ninhydrin colorimetric analysis for amino acids. Arch Biochem Biophys. 1957;67(1):10-5. https://doi.org/10.1016/00039861(57)90241-2.

25. Singleton VL, Orthofer R, Lamuela-Raventós RM. Analysis of total phenols and other oxidation substrates and antioxidants by means of FolinCiocâlteu reagent. Meth Enzymol. 1999;299(1):152-78. https://doi.org/10. 1016/S0076-6879(99)99017-1

26. Ballard TS, Mallikarjunan P, Zhou K, O'keefe SF. Optimizing the extraction of phenolic antioxidants from peanut skins using response surface methodology. J Agic Food Chem. 2009;57(8):3064-72. https://doi.org/10. 1021/jf8030925.

27. Morales G, Paredes A. Antioxidant activities of Lampaya medicinalis extracts and their main chemical constituents. BMC Complementary Altern Med. 2014:14(259):1-12. https://doi.org/10.1186/1472-6882-14-259.

28. Lee J, Durst RW, Wrolstad RE. Determination of total monomeric anthocyanin pigment content of fruit juices, beverages, natural colorants, and wines by the pH differential method: collaborative study. J AOAC Int. 2005;88(5):1269-78.

29. Ordoudi SA, Tsimidou MZ, Vafiadis AP, Bakalbassis EG. Structure-DPPH scavenging activity relationships: parallel study of catechol and guaiacol acid derivatives. J Agric Food Chem. 2006;54(16):5763-8. https://doi.org/10 1021/jf060132x.

30. Mosmann T. Rapid colorimetric assay for cellular growth and survival: application to proliferation and cytotoxicity assays. J Immunol Methods. 1983;65(1-2):55-63. https://doi.org/10.1016/0022-1759(83)90303-4.

31. Suffness $M$, Pezzuto JM. Assays related to cancer drug discovery. In: Hostettmann K, editor. Methods in plant biochemistry: assays for bioactivity. London: Academic Press; 1990. p. 71-133.

32. Moo-Puc R, Robledo D, Freile-Pelegrín Y. In vitro cytotoxic and antiproliferative activities of marine macroalgae from Yucatán. México Cienc Mar. 2009;35(4):345-58. https://doi.org/10.1158/1940-6207.PREV09-B78.

33. Halle W. The registry of cytotoxicity: toxicity testing in cell cultures to predict acute toxicity $\left(\mathrm{LD}_{50}\right)$ and to reduce testing in animals. Altern Lab Anim. 2003;31(2):89-198.

34. Hseu Y-C, Lee C-C, Chen Y-C, Senthil-Kumar KJ, Chen C-S, Huang Y-C, Hsu L-S, Huang H-C, Yang H-L. The anti-tumor activity of Antrodia salmonea in human promyelocytic leukemia (HL-60) cells is mediated via the induction of $\mathrm{G} 1$ cell-cycle arrest and apoptosis in vitro or in vivo. J Ethnopharmacol. 2014;153(2):499-510. https://doi.org/10.1016/j. jep.2014.03.012.

35. Costa-Rodrigues-Alves AB, Souza-Dos Santos R, De Santana-Calil S, Niero R, Da Silva-Lopes J, Perazzo FF, Pires-Rosa PC, Faloni-Andrade S, Cechinel-Filho $\checkmark$, Maistro EL. Genotoxic assessment of Rubus imperialis (Rosaceae) extract in vivo and its potential chemoprevention against cyclophosphamide-induced DNA damage. J Ethnopharmacol. 2014;153(3):694-700. https://doi.org/10. 1016/j.jep.2014.03.033.

36. Dhawan A, Bajpayee M, Pandey AK, Parmar D. ITRC: the SCGE/comet assay protocol. http://www.cometassayindia.org/ protocol\%20for\%20comet\%20assay.pdf (2009). Accessed 17 Mar 2019.

37. Oparka M, Walczak J, Malinska D, Van Oppen LMPE, Szczepanowska J, Koopman WJH, Wieckowski MR. Quantifying ROS levels using $\mathrm{CM}-\mathrm{H}_{2} \mathrm{DCFDA}$ and HyPer. Methods 2016; 109(2016): 3-11. doi:https://doi.org/10.1016/j. ymeth.2016.06.008

38. Eskes C, Whelan M. Validation of alternative methods for toxicity testing. In: Advances in experimental medicine and biology. Switzerland: Springer; 2016. p. 1-406. https://doi.org/10.1007/978-3-319-33826-2.

39. Secretaría de Agricultura, Ganadería, Desarrollo Rural, Pesca y Alimentación. Norma Oficial Mexicana NOM-062-ZOO-1999: Especificaciones técnicsas para la producción, cuidado y uso de los animales de laboratorio. https:// www.gob.mx/cms/uploads/attachment/file/203498/NOM-062-ZOO-1999_ 220801.pdf (2001). Accessed 17 Mar 2019.

40. OECD. Test no. 425, acute oral toxicity (up-and-down procedure). In: OECD Guidelines for the testing of chemicals, section 4. Paris: OECD; 2008. https:// doi.org/10.1787/9789264071049-en.
41. Gomez-Campos R, De Arruda M, Cossio-Bolaños MA. Validity of somatic equations for predicting body composition male Wistar rats. Actualización en nutrición. 2011;12(1):60-6.

42. Taiz L, Zeiger E. Plant Physiology EEUU : Sinauer Associates; 2006. 1-690.

43. Jungmin O, Heonjoo J, Ah Reum C, Sung-Jin K, Jaejoon H. Antioxidant and antimicrobial activities of various leafy herbal teas. Food Control 2013; 31(2): 403-409. doi:https://doi.org/10.1016/j.foodcont.2012.10.021.

44. Lambert JD, Elias RJ. The antioxidant and pro-oxidant activities of green tea polyphenols: a role in cancer prevention. Arch Biochem Biophys. 2011; 501(1):65-72. https://doi.org/10.1016/j.abb.2010.06.013.

45. Boyd MR. NCl: in vitro anticancer drug discovery screen. Concept, implementation, and operation. https://home.ncifcrf.gov/mtdp/catalog/full_ text/paper309/paper309.pdf (1995). Accessed 17 Mar 2019.

46. Adeneye AA, Ajagbonna OP, Adeleke TI, Bello SO. Preliminary toxicity and phytochemical studies of the stem bark aqueous extract of Musangacecropioides in rats. J Ethnopharmacol. 2006;105(3):374-9. https:// doi.org/10.1016/j.jep.2005.11.027.

47. Kawk SH, Kang YR, Kim YH. 1,2,3,4,6-Penta-O-galloyl- $\beta$-d-glucose suppresses colon cancer through induction of tumor suppressor. Bioorg Med Chem Lett. 2018;28(12):2117-23. https://doi.org/10.1016/j.bmcl.2018. 05.028 .

48. Shin H, Park Y, Choi JH, Jeon YH, Byun Y, Sung SH, Lee KY. Structure elucidation of a new triterpene from Rhus trichocarpa roots. Magn Reson Chem. 2017;55(8):763-6. https://doi.org/10.1002/mrc.4574.

49. Gross GG. Enzymes in the biosynthesis of hydrolyzable tannins. In: Hemingway RW, Laks PE, Branham SJ, editors. Plant polyphenols: synthesis, properties, significance. New York: Springer; 1992. p. 43-60.

50. Hwang IG, Kim HY, Woo KS, Lee SH, Lee J, Jeong HS. Isolation and identification of the antioxidant DDMP from heated pear (Pyrus pyrifolia Nakai). Prev Nutr Food Sci. 2013;18(1):76-9. https://doi.org/10.3746/pnf.2013. 18.1.076.

51. Sang-Bong L, Hae-Ryong P. Anticancer activity of guava (Psidium guajava L.) branch extracts against HT-29 human colon cancer cells. J Med Plants Res. 2010;4(10):891-6. https://doi.org/10.5897/JMPR10.043.

52. Yaswen $P$, Mackenzie KL, Keith WN, Hentosh P, Rodier F, Zhu J, Firestone GL, Matheu A, Carnero A, Bilsland A, Sundin T, Honoki K, Fujii H, Georgakilas AG, Amedei A, Amin A, Helferich B, Boosani CS, Guha G, Ciriolo MR, Chen S, Mohammed SI, Azmi AS, Bhakta D, Halicka D, Niccolai E, Aquilano K, Ashraf SS, Nowsheen S, Yang X. Therapeutic targeting of replicative immortality. Semin Cancer Biol. 2015;35(Suppl):S104-28. https://doi.org/10.1016/j. semcancer.2015.03.007.

53. Bonkovsky HL. Hepatotoxicity associated with supplements containing Chinese green tea (Camellia sinensis). Ann Intern Med. 2006;144(1):68-71. https://doi.org/10.7326/0003-4819-144-1-200601030-00020.

54. Yang GY, Liao J, Li C, Chung J, Yurkow EJ, Ho CT, Yang CS. Effect of black and green tea polyphenols on c-Jun phosphorylation and $\mathrm{H}(2) \mathrm{O}(2)$ production in transformed and non-transformed human bronchial cell lines: possible mechanisms of cell growth inhibition and apoptosis induction. Carcinogenesis. 2000;21(11):2035-9. https://doi.org/ 10.1093/carcin/21.11.2035

55. Amin A, Karpowicz PA, Carey TE, Arbiser J, Nahta R, Chen ZG, Dong JT, Kucuk O, Khan GN, Huang GS, Mi S, Lee HY, Reichrath J, Honoki K, Georgakilas AG, Amedei A, Amin A, Helferich B, Boosani CS, Ciriolo MR, Chen S, Mohammed SI, Azmi AS, Keith WN, Bhakta D, Halicka D, Niccolai E, Fujii H, Aquilano K, Ashraf SS, Nowsheen S, Yang X, Bilsland A, Shin DM. Evasion of anti-growth signaling: a key step in tumorigenesis and potential target for treatment and prophylaxis by natural compounds. Semin Cancer Biol. 2015;35(Suppl):S55-77. https:// doi.org/10.1016/j.semcancer.2015.02.005.

56. Amin A, Hamza AA, Daoud S, Khazanehdari K, Hrout AA, Baig B, Chaiboonchoe A, Adrian TE, Zaki N, Salehi-Ashtiani K. Saffron-based crocin prevents early lesions of liver cancer: in vivo, in vitro and network analyses. Recent Pat Anticancer Drug Discov. 2016;11(1):121-33. https://doi.org/10. 2174/1574892810666151102110248

57. Khan SA, Priyamvada S, Khan W, Khan S, Farooq N, Yusufi AN. Studies on the protective effect of green tea against cisplatin induced nephrotoxicity. Pharmacol Res. 2009;60(5):382-91. https://doi.org/10. 1016/j.phrs.2009.07.007.

58. Na HK, Surh YJ. Modulation of Nrf2-mediated antioxidant and detoxifying enzyme induction by the green tea polyphenol EGCG. Food Chem Toxicol. 2008;46(4):1271-8. https://doi.org/10.1016/j.fct.2007.10.006. 
59. Stevens T, Qadri A, Zein NN. Two patients with acute liver injury associated with use of the herbal weight-loss supplement hydroxycut. Ann Intern Med. 2005;142(6):477-8. https://doi.org/10.7326/0003-4819142-6-200503150-00026.

60. Shin SH, Koo KH, Bae JS, Cha SB, Kang IS, Kang MS, Kim HS, Heo HS, Park MS, Gil GH, Lee JY, Kim KH, Li Y, Lee HK, Song SW, Choi HS, Kang BH, Kim JC. Single and 90-day repeated oral dose toxicity studies of fermented Rhus verniciflua stem bark extract in Spraque-Dawley rats. Food Chem Toxicol. 2013;55(2013):617-26. https://doi.org/10.1016/j.fct. 2013.01.043.

\section{Publisher's Note}

Springer Nature remains neutral with regard to jurisdictional claims in published maps and institutional affiliations.

Ready to submit your research? Choose BMC and benefit from:

- fast, convenient online submission

- thorough peer review by experienced researchers in your field

- rapid publication on acceptance

- support for research data, including large and complex data types

- gold Open Access which fosters wider collaboration and increased citations

- maximum visibility for your research: over $100 \mathrm{M}$ website views per year

At BMC, research is always in progress.

Learn more biomedcentral.com/submissions 